\title{
Turris Babel inside. II disvelamento della materia tra frammento e rottura
}

\author{
Chiara Pietropaolo
}

\section{Abstract}

La ricerca si occupa di un tema alquanto singolare dal punto di vista della rappresentazione della torre di babele nella storia dell'arte. La turris babel acquisisce un nuovo significato visivo in quanto la ricerca intraprende un percorso volto alla scoperta e all'interpretazione di essa intimamente, grazie al concetto di 'vision' e di 'visione', parametri fondanti nel processo di mutazione della forma iconica della torre. Viene pertanto scoperto un nuovo significato e una nuova forma rappresentativa, per mezzo di una modellazione materica del modello della torre, che 'rompe' la conformazione tradizionale, ideandone una sua trasformazione formale. La rottura, il venir meno della materia, libera nuove figure e nuove 'visioni', consentendo di sviluppare uno studio i cui esiti intraprendono la possibilità di incidere profondamente sulla forma dell'architettura, mutandone la sua configurazione iniziale. Caso studio della ricerca è la più iconica delle torri prodotte dall'arte fiamminga del xvi secolo: la Grande torre di babele di Pieter Bruegel il vecchio (1563). Nuovi modi della rappresentazione prendono quindi piede in questa ricerca e fanno spazio a nuovi punti di osservazione, nell'eterna rappresentazione di un archetipo senza tempo, paradigma fondamentale per l'iconografia della torre più discussa nella storia dell'umanità.

Turris Babel, inside vision, archetipo, disvelamento, rottura.
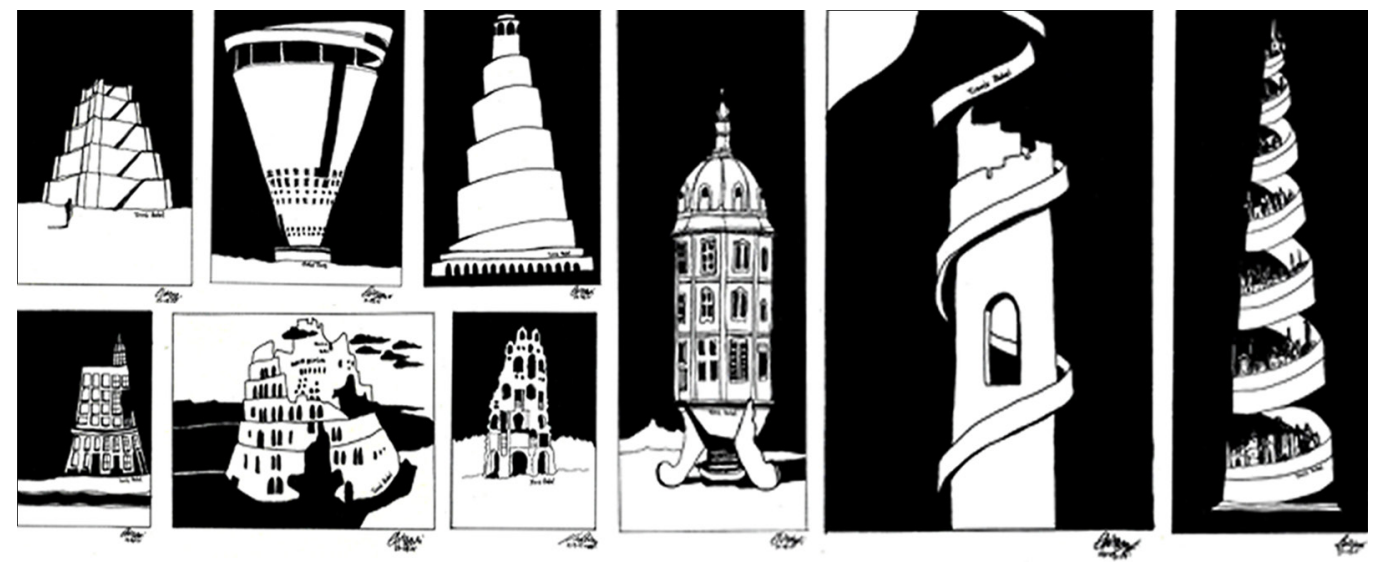
"Controllare il destino della forma, è cosa sempre concessa alla pittura e alla scultura, quasi mai alla costruzione

[Massimo Scolari]

\section{Architettura della forma. La funzione dell'archetipo}

"Gli Archetipi ci indicano laconicamente la via verso la precisione e l'accuratezza formale. Essi sono le forme base dell'architettura studiata nei suoi rapporti con la natura, vista in maniera indipendente dal suo contesto" [Scolari 1979, p. 44].

É infatti nelle figure degli archetipi, in quel "rispetto per l'Archetipo" che, come dice Scolari, ci si oppone all'"'ostinato innovare", ritrovando la natura di macchina dell'architettura: la torre di Babele è uno di questi primissimi esempi [Scolari 1991, p. 7], uno degli archetipi più indagati, ricorrendo con grande frequenza nella storia dell'arte. Essa rappresenta la gradonatura naturale delle montagne trasformata in architettura, quindi il principio stesso della costruzione. Così, Babele incarna il concetto primigenio di divulgazione di un patrimonio simbolico, letterario, archeologico-architettonico, mitologico-biblico e letterario. Riunisce in sè un bagaglio culturale plurimo, e si inserisce all'interno di un tema che abbraccia il sapere globale della conoscenza umana.

La scelta di questo tema prende avvio dalla constatazione che lo studio della tipologia architettonica della torre rappresenta il più diffuso modello architettonico e urbano della storia dell'architettura antica fin dalle prime civiltà. Si mette, quindi, in evidenza questa figura archetipa nelle sue espressioni materiali ed immateriali, soprattutto attraverso la pittura, dove il tema è un pretesto per argomentare i procedimenti della rappresentazione (figg. I, 7).

Un prezioso apporto dal punto di vista dei paradigmi archetipici a fondamento della forma della torre di Babele, si è generato dalle ricerche di Hermann Kern e Paolo Santarcangeli, e con essi Baltrusaitis, Borges, Eco, Hillman, Jung e Kircher, che nel suo Turris Babel [Kircher 1679] ci mostra un'interessante riflessone sul tema della torre come archetipo ancestrale, da un punto di vista scientifico.

Per quanto riguarda la concezione formale, un aspetto originale della ricerca in relazione a questo archetipo, lo si deve proprio a Scolari, il quale riconosce l'identità tra la torre come costruzione elevata e la spaccatura che si genera al suo interno. Si crea pertanto un vuoto che deve essere colmato, diventando così un pieno, cioè una seconda architettura.

Possiamo notare quindi, che qualcosa permea il centro della torre. Qualcosa attraversa quella spaccatura. Una rottura, una lacerazione che genera però un frammento. Una nuova immagine.

Fig. I. Archetipi a confronto a) Massimo Scolari, Turris Babel, 1982. Acquerello su carta (sinistra);
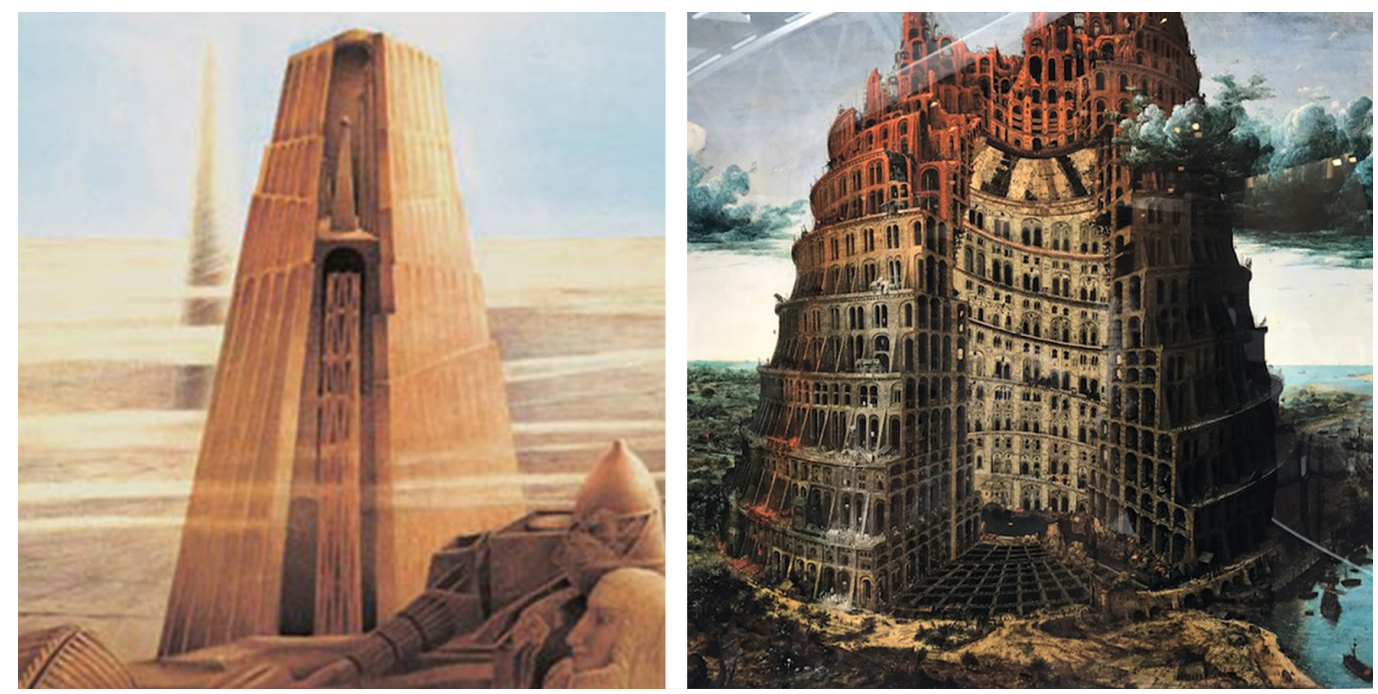
Una nuova visone. Una Babel, Inside. In un certo senso, vi è in Scolari un intento di scavare in profondità. Di ricercare il lato nascosto delle cose.

Ecco perchè questo capolavoro lo accostiamo all'Inside Babel di Katsuhiro Otomo [I]: nel comune intento volto alla ricerca dell'interiorità architettonica, entrambi gli artisti producono visioni che si inseriscono all'interno di un progetto di ricerca. Un progetto che va la di là delle storiche visioni utopiche della torre 'integra' (fig. 2).

L'idea nasce proprio dal principio cardine di condurre la ricerca sulla forma, attraverso una serie di figure, viste come scomposizione di insiemi complessi. A conferma di questo assunto, possiamo affermare che la torre di Babele compare come l'elemento di certezza nella ricerca che trova in questi elementi le figure archetipiche e i principi a cui affidare la sostanza delle scelte intraprese [Pizzigoni 20I I, pp. I- I7].
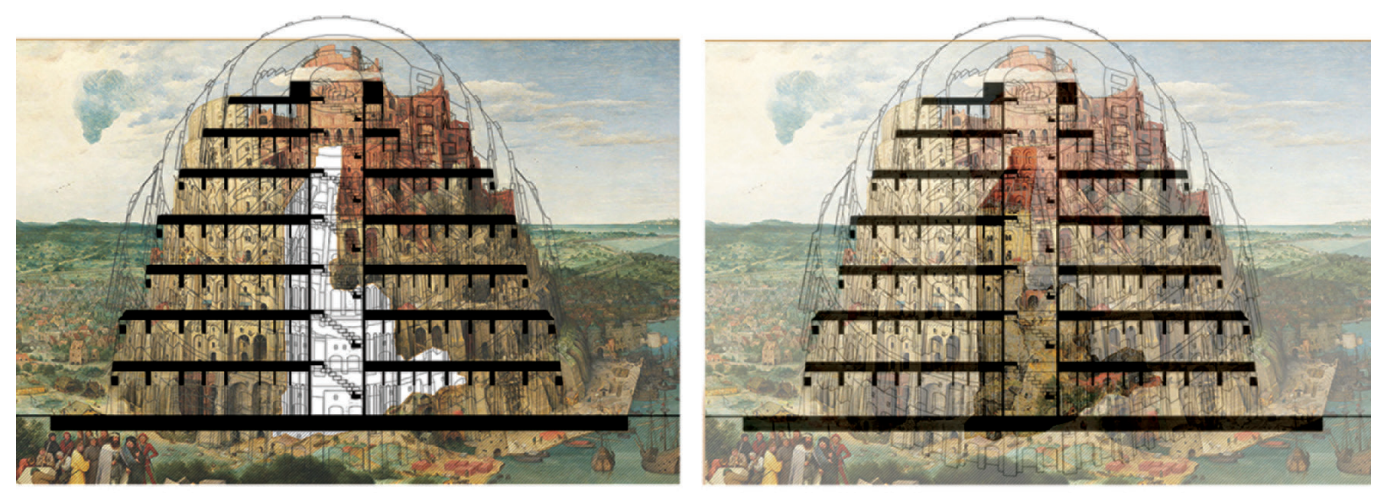

Fig. 2. Architetture della Visione. Studi per l'estrapolazione della vision pittorica nel caso studio. Bruegel's Tower of Babel Inside Vision, 2019 (elaborazione grafica Chiarazietropalic
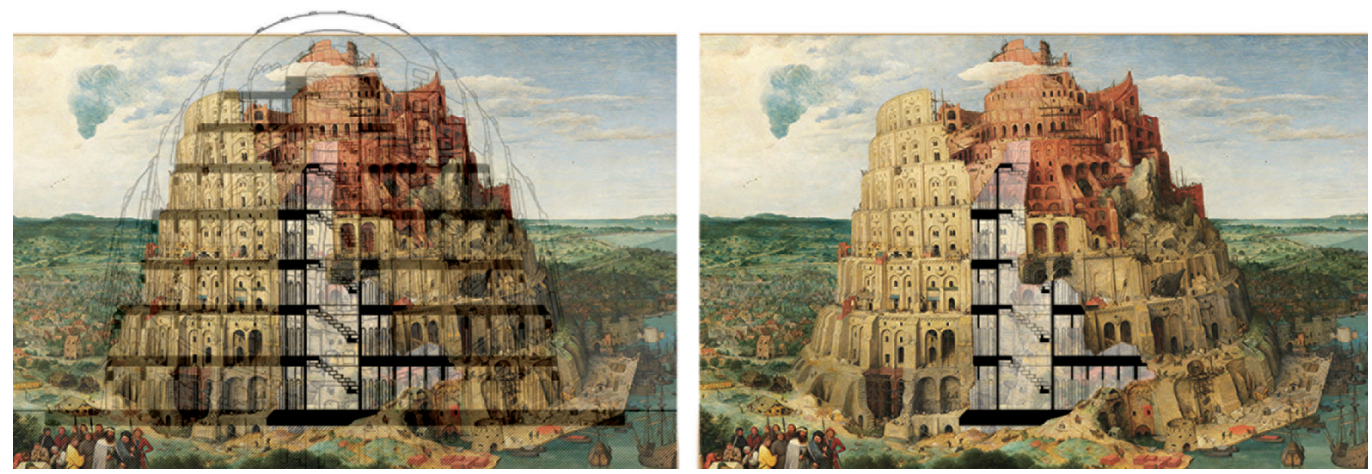

\section{Rottura e trasformazione. Turris Babel Inside Vision: il disvelamento della materia}

Ma gli archetipi sono anche immagini sintetiche che non sempre si concretizzano in progetti rispondenti alle richieste della realtà costituita. Proprio per tale motivo sono ricchi di significato e vengono definiti 'visionari'.

Hanno bisogno di uno sguardo che fuoriesca dalla città e dai suoi caratteri geografici, per assumere quel valore simbolico che la ricerca tanto persegue. Architetture dei 'punti limite' sono quindi nella maniera più chiara ed evidente quegli archetipi che segnano il passaggio tra due mondi. E la Turris Babel incarna appieno questo concetto di passaggio tra mondo terreno e mondo celeste. Ancora una volta il riferimento all'opera di Otomo è più che mai calzante.

La Turris Babel si mostra ai nostri occhi 'inside', internamente, da un punto di vista che la 'lacera' al suo interno, scavata in profondità, 'scarnificata', diventando essa stessa un 'frammento', un nuovo 'frammento' che prende vita dalla rottura, dalla lacerazione dell'oggetto architettonico (la torre), che è esso stesso un Archetipo, uno di quegli archetipi fondamentali nella storia dell'architettura, e che genera un qualcosa di nuovo: una visone. Inside Babel 
Fig. 3. Dal dipinto alla 'scar nificazione' del modello come metodo di disvelamento della materia. The "small tower" of Babel by Pieter Bruegel according to Otomo.
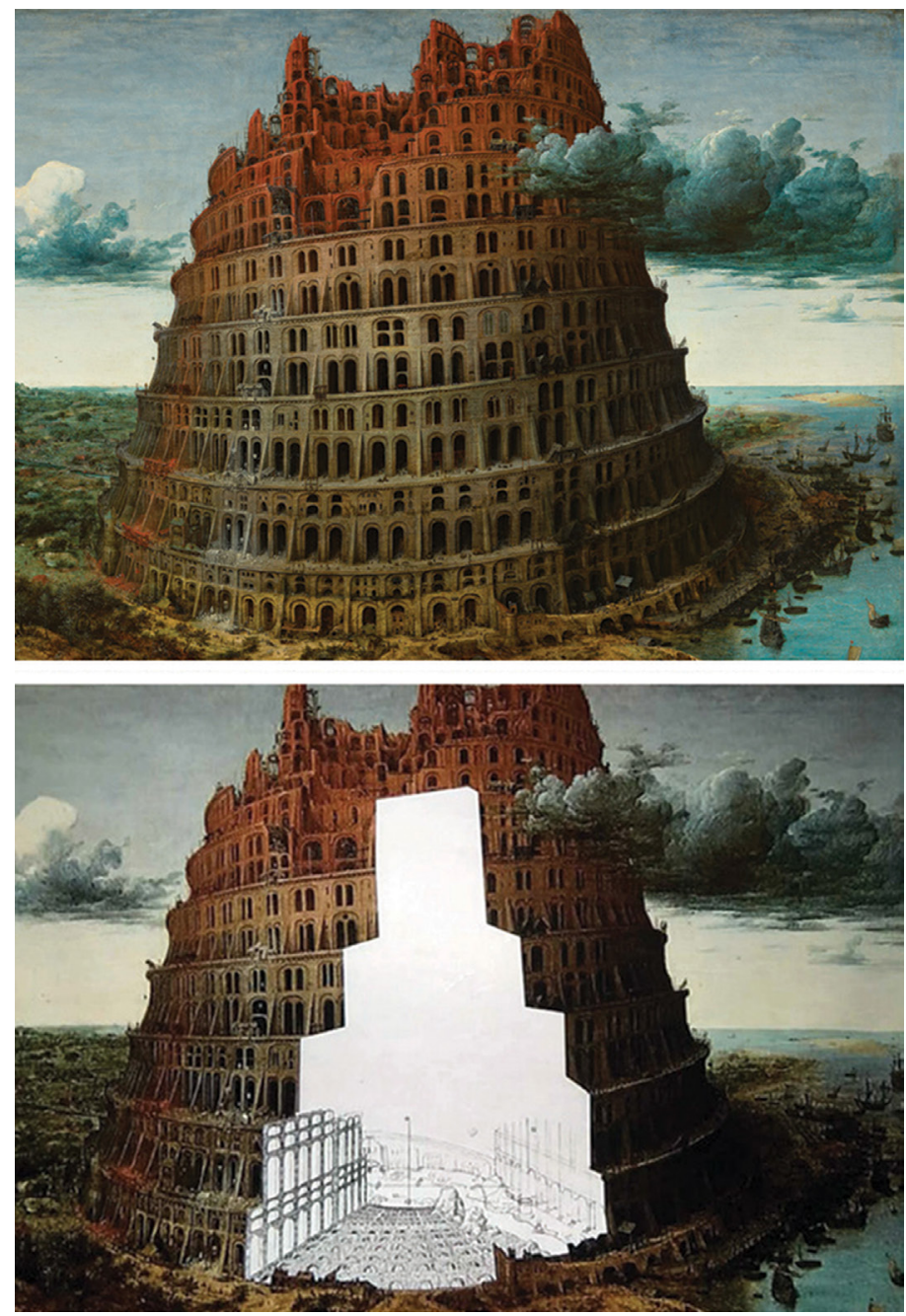

assume quindi un carattere 'visionario', diventa un progetto utopico aderente alla visionarietà delle cose terrene che però gettano uno sguardo proiettato verso il futuro (figg. 3, 4, 5). A dimostrazione di ciò, ricorrono le rappresentazioni di Massimo Scolari, le quali ben si intrecciano con le tematiche della ricerca su Turris Babel. In particolar modo, sul concetto di 'rottura' e di 'frammento' dell'architettura, proprio perchè in esse vi troviamo sintetizzati alcuni degli elementi fondanti del racconto visionario. La messa in scena di un mondo parallelo, in cui l'apparente nostalgia per gli archetipi architettonici delle antiche culture mediorientali e mediterranee è tenuta a bada da uno sguardo amante dell'enigma. Pertanto ogni progetto legato ad essi sarà un progetto 'visionario', poichè appartiene a questo mondo che si contrappone all'ordinarietà delle cose e si sopraeleva ad una dimensione altra, che sta al di sopra delle cose stesse [Pizzigoni 20। I, pp. I- I7].

Ma che cos'è l'architettura del frammento e della rottura? Si potrebbe definire come architettura della frammentarietà, quell'architettura che genera in se stessa la rottura, la lacerazione, lo scavo in profondità, il venir meno dei tipi edilizi, tutte varianti che permettono un viaggio attraverso la sua interiorità nella possibilità di incidere molto profondamente sulla forma dell'architettura stessa.

Scrive Aldo Rossi: “'Frammento' è un piccolo pezzo staccato per frattura da un corpo qualunque. E con ciò, esso esprime una speranza, ancora una speranza, e come tale non conviene con rottame, che esprime una moltitudine o un aggregato di cose rotte. In questa dizione, rottame potrebbe essere il corpo della città futura se le cose non dovessero cambiare e sempre più fosse accettato il disordine e poco meditata la previsione del futuro. [...] 
Fig. 4. Tavola di sintesi sul Bruegel's Tower of Babel Inside Processing 2019. Rielaborazione grafica sulla base del lavoro svolto da Annalisa Frattarelli / Katsuhino Otomo.
Per questo credo anche nella città futura come quella dove si ricompongono i frammenti di qualcosa di rotto dall'origine" [Rossi 1987, p. 7].

Architettura del frammento o della rottura è anche quella che Scolari chiama "border architecture".

Una ricerca sugli archetipi, elementi che sono costanti nell'architettura e che non dipendono dalla sua condizione urbana, deve necessariamente prendere avvio da questa 'architettura del limite'.

Per Scolari, difatti, è indagando sull'architettura dei punti limite che si ritrovano gli archetipi. Senza rottura, quindi, non c'è cesura. Senza rottura non c'è verità. E la ricerca della verità sta nella ricerca dell'interiorità. Questo è il vero obiettivo da perseguire.
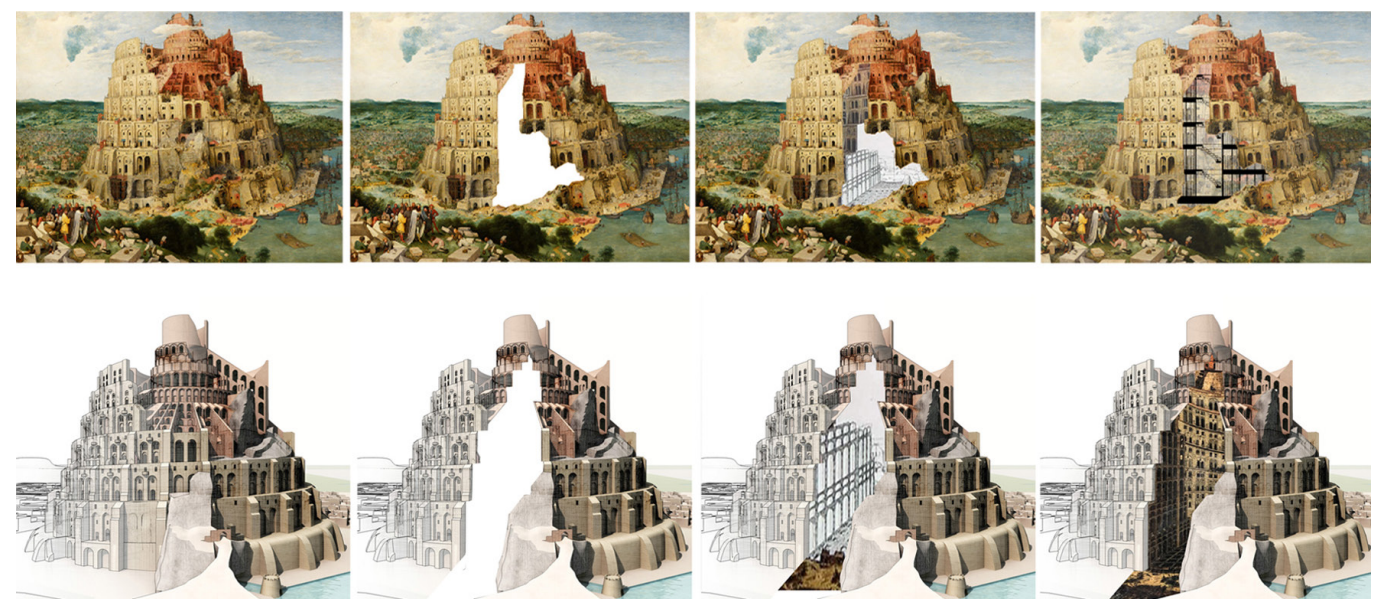

\section{Una nuova configurazione. Dalla Vision pittorica alla Vision materica}

Così, il concetto di 'vision' e di 'visione' prendono forma, grazie alla vera e propria realizzazione della torre di Babele di Bruegel, oggetto di studio. Un nuovo metodo, quindi, la fase in opera, per una nuova rappresentazione, tramite l'analisi e l'elaborazione di sezioni immaginarie (Inside Section), la cui estrapolazione ha permesso di condurre un processo di 'disvelamento' della materia, nonché la realizzazione di una 'vision reale', che prende avvio dalla 'rottura' dell'Outside Babel (l'involucro esterno della torre), e disvela/rivela appunto la sua interiorità architettonica [2] (fig. II).

II risultato è una Turris Babel che si mostra in duplice aspetto: in essa, Outside e Inside Babel convivono perfettamente in un unico archetipo (fig. 6).

All'ordinarietà della visione [3], viene contrapposta una nuova visione, reale, materiale, rispondente ai requisiti di concretezza, tridimensionalità e veridicità; determinata dalla realizzazione di un modello materico in gesso, in tre differenti versioni:

I. Outside Babel model;

2. Inside Babel model;

3. Frammenti generati dalla rottura di Outside Babel e Inside Babel model, mediante un processo di disvelamento dell'architettura della torre di Babele (figg. I0, I I).

La struttura del modello è stata realizzata in argilla prima e in gesso poi, con conseguente frammentazione dello stesso in seguito ad una rottura spontanea della scagliola che ha determinato così le interiorità dalle quali sono state poi generate e messe a punto le sezioni sopracitate. A tal fine, si rende noto che la 'scarnificazione' del modello, in questa fase finale, prende pienamente forma, grazie alla modellazione concreta della materia (il gesso), permettendo di ampliare lo scenario visibile affrontato da Otomo. Le immagini che seguono nelle pagine successive, mostrano chiaramente questo percorso di disvelamento della materia (figg. 8, 9). 

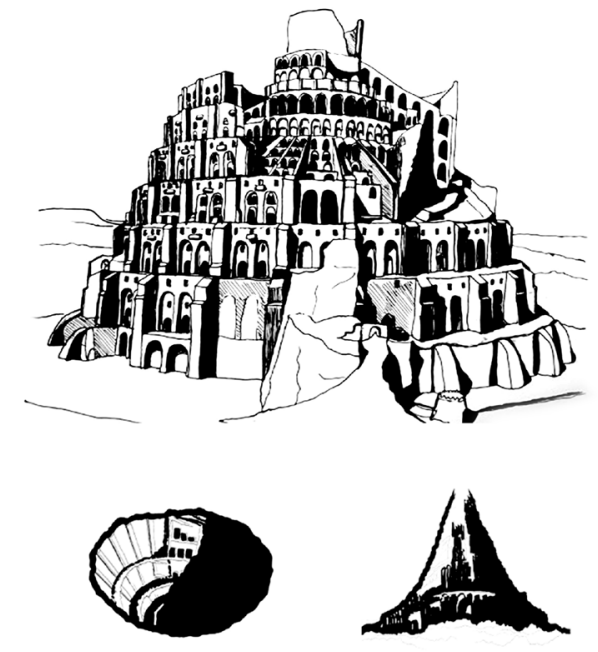

"INSIDE" BABEL

NEGATIVE shape

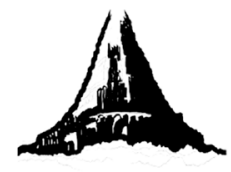

"OUTSIDE" BABE

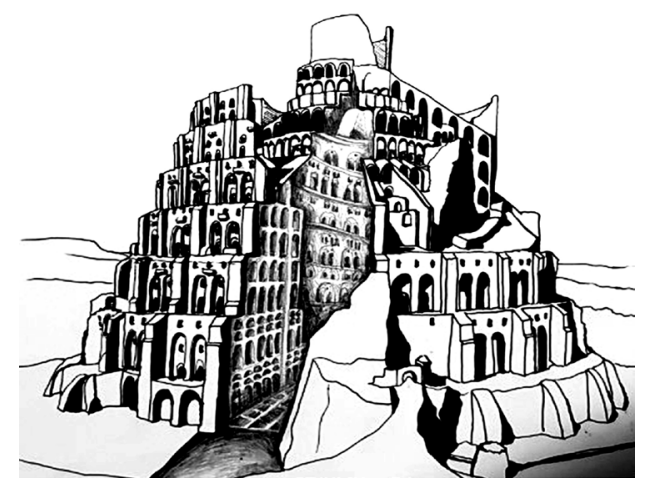

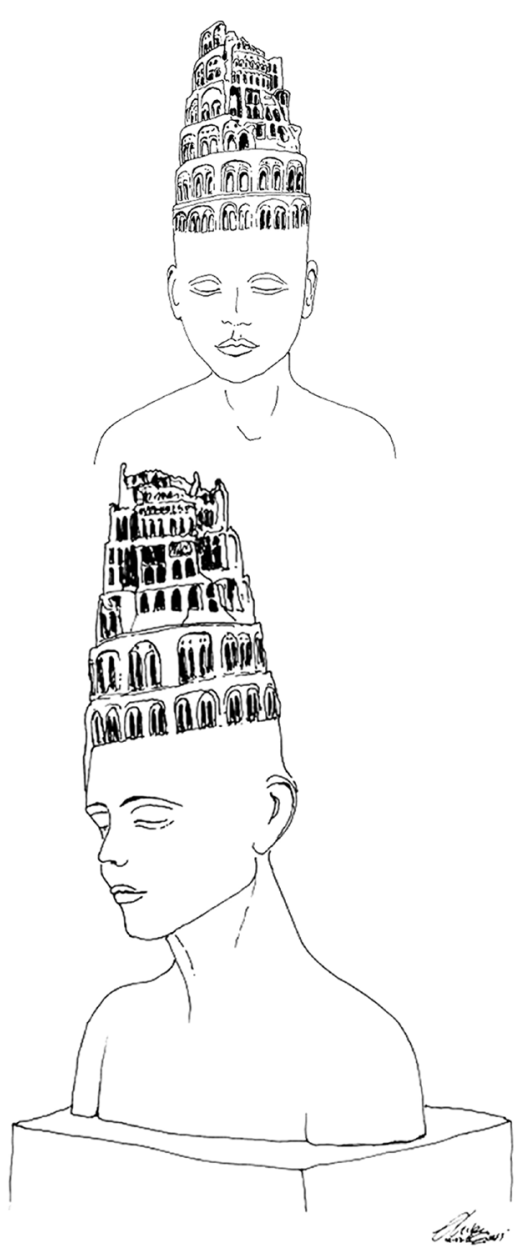


Inoltre, è stata condotta un'analisi dettagliata tramite software CAD, per poter rappresentare al meglio con il metodo delle proiezioni ortogonali, le suddette sezioni.

Partendo da una serie fotografica dei vari frammenti determinati dalla rottura dei modelli della torre in gesso (Outside e Inside), sono state scelte tre sezioni tipo, da sottoporre ad uno studio comparato. In esse sono state messe in evidenza le parti 'rotte', frammentate dalla caduta e/o dalla spontanea rottura del materiale gessoso, evidenziandole con un pigmento di color rossastro.

Successivamente, la ricerca ha estrapolato una sola sezione delle tre prese in esame, da poter analizzare in ultima fase nella sua totalità, per poter al meglio tradurre i concetti cardine preposti, quali la 'scarnificazione', la 'rottura' e il 'disvelamento' della materia intrinseca all'interno della torre di Babele (Inside Babel).

Al disvelare della materia, infatti, ne consegue una sua rappresentazione non solo formale, ma anche tridimensionale nel vero senso del termine: la ricerca conclude il suo percorso di ricerca dell'interiorità, dando perlopiù vita ad una Inside Section tipo, per mezzo di un'attenta analisi tramite il disegno ortogonale delle sue fratture (fig. I 2).

Nello specifico, è stata presa in esame una delle varie sezioni analizzate, effettuando una serie fotografica dei frammenti generati dalla rottura del modello in gesso della torre (Inside section type) [4].

\section{Conclusioni e avanzamento della ricerca}

La ricerca si è focalizzata sull'elaborazione di una 'vision', una rielaborazione dell'immagine dipinta mostrandola 'scarnificata' al suo interno, sulla base del progetto operato da Katsuhiro Otomo per la 'piccola' torre di Babele del noto pittore fiammingo Bruegel. Operando una traduzione del modello mostrato dal maestro giapponese, si è proceduto poi alla costruzione del modello materico in gesso, applicando lo 'svuotamento' (Inside Babel) della 'grande' torre di Babele dello stesso Bruegel. Dei tre modelli realizzati, si è ottenuto poi il disvelamento dell'architettura della torre, con conseguente raccolta e catalogazione dei risultati infine ottenuti.

L'obiettivo finale è stato quello di aver dimostrato attraverso le forme della rappresentazione quell'architettura utopica che nell'archetipo della torre diventa mito, nelle sue valenze materiali e immateriali.

La rottura, il venir meno della materia, ha liberato nuove figure e nuove 'visioni', consentendo di sviluppare, in un rinnovato campo di indagine, uno studio i cui esiti intraprendono la possibilità di incidere profondamente sulla forma dell'architettura, mutandone la sua configurazione iniziale.

II valore aggiunto sta nell'aver cercato di offrire originali metodi d'interpretazione, contribuendo alla trasmissione di un modello utopico che assume valore in quanto memoria per la rappresentazione di valori identitari che si costituiscono come beni insostituibili per la storia dell'umanità. E la ricerca proprio questo ha cercato di costruire.

Tale procedimento è servito a veder la Turris Babel in profondità, interpretandola nella sua dimensione esatta, quella nascosta all'interno del corpo di fabbrica convenzionalmente inteso, ma non percepito intimamente. Per portare alla luce la sua forza e la sua potenza espressiva è stato necessario scavare in profondità. Una profondità accessibile solo nel mondo della 'visione'. Una visione che lascia intravedere la vera essenza della torre.

\section{Note}

[I] Si veda il lavoro di Katsuhiro Otomo, "Inside Babel" in due versioni, ambedue esposte in una recente mostra frutto della collaborazione del Museum Boijmans Van Beuningen di Rotterdam, che ha "inviato" la sua Collection "Bruegel's. The Tower of Babel and Great 16th Century Masters" in Giappone, ospitata al Tokyo Metropolitan Art Museum e successivamente al National Museum of Art di Osaka nell'anno 2017.

[2] L'Inside Babel" progettata da Otomo e contestualizzata nella ricerca grazie alla fase in opera che ha potuto così tradurre la "Vision grafica" o visuale in "Vision materica" o reale. 


\section{OUTSIDE BABEL}

$-1^{\circ}$ fase: Bozzetto scultoreo

$-2^{\circ}$ fase: Modellazione

Preparazione dello scheletro di sostegno

$-3^{\circ}$ fase: Modellazione

Modellazione in argilla (corpo) e gesso (base)
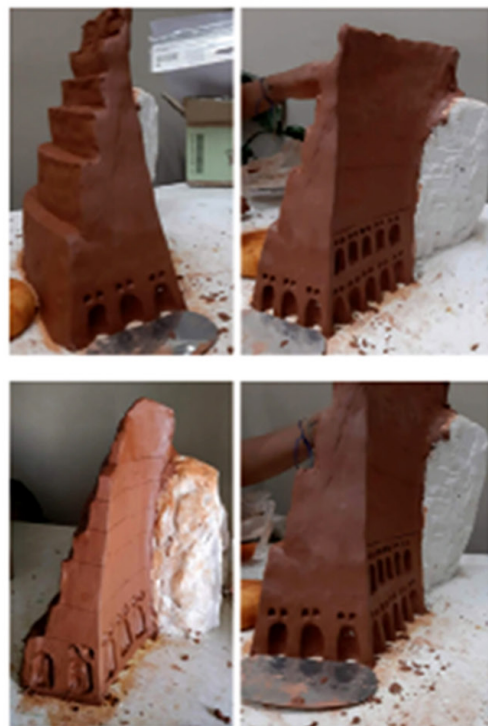

$-4^{\circ}$ fase: Modellazione

Disegno, incisione e rifinitura degli archi dell'involucro estemo ("Outside Babel")

$-5^{\circ}$ fase: Formatura in Silicone 1. Preparazione dei richiami per la forma in silicone

2. Stesura del primo strato in silicone

$-6^{\circ}$ fase: Formatura in Gesso

1. Realizzazione del controstampo in gesso scagliola

2. Formatura del primo positivo in gesso

Fig. 7. Fasi di lavorazione el modello in gesso della Torre di Babele di
Pieter Bruegel: involucro esterno, Outside Babel.
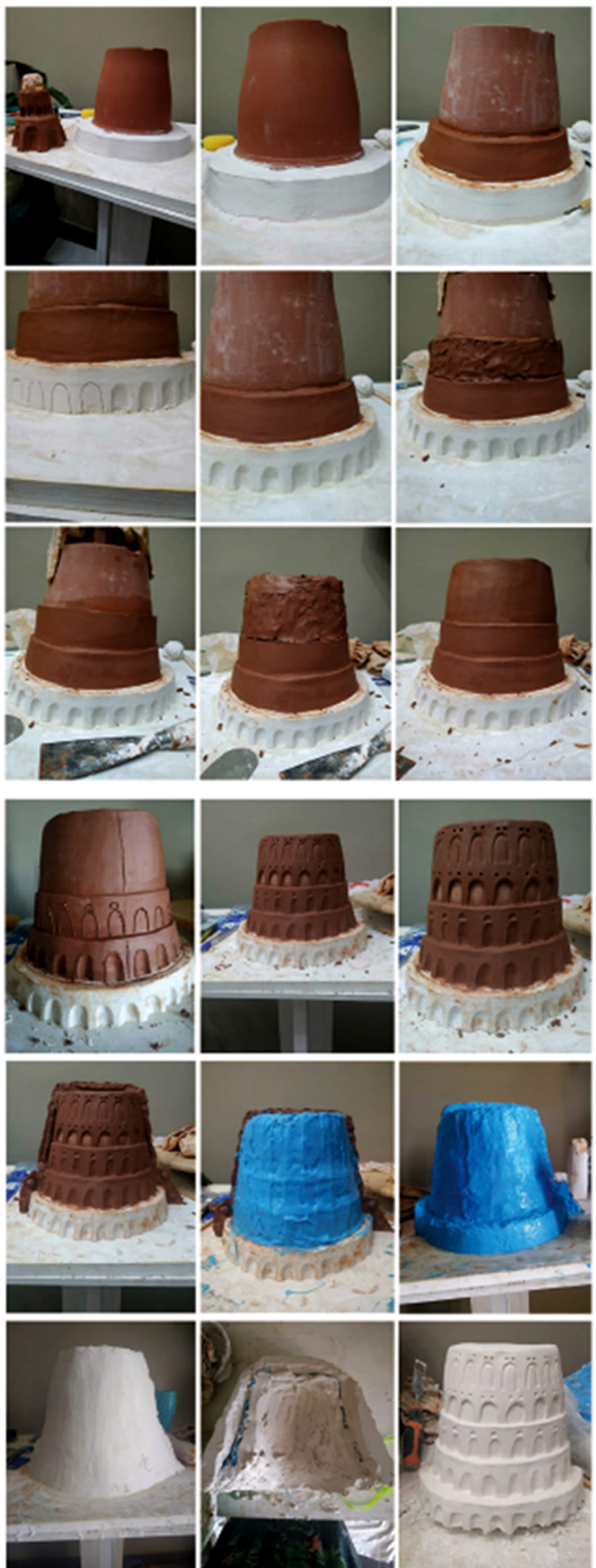


\section{INSIDE BABEL}

- $7^{\circ}$ fase: Modellazione Modellazione in argilla del volume interno alla torre ("Inside Babel") Disegno, incisione e rifinitura degli archi dello spaccato interno ("Inside Babel")

$-9^{\circ}$ fase: Formatura in Silicone

1. Preparazione del modellato per la realizzazione del negativo in silicone 2. Stesura del silicone per la realizzazione del negativo in gesso scagliola

$-10^{\circ}$ fase: Formatura in Gesso

1. Realizzazione di uno stampo bivalve

2. Realizzacione di un controstampo di contenimento 3. Formatura del modello in gesso scagliola (positivo)

Fig. 8. Fasi di lavorazione Torre di Babele di Pieter Bruegel: struttura intern Inside Babel.

-11ํase: Sformatura e Rifinitura

1. Sformatura e rifin tura del modello in gesso scagliola

2. Patinatura
- $8^{\circ}$ fase: Modellazione
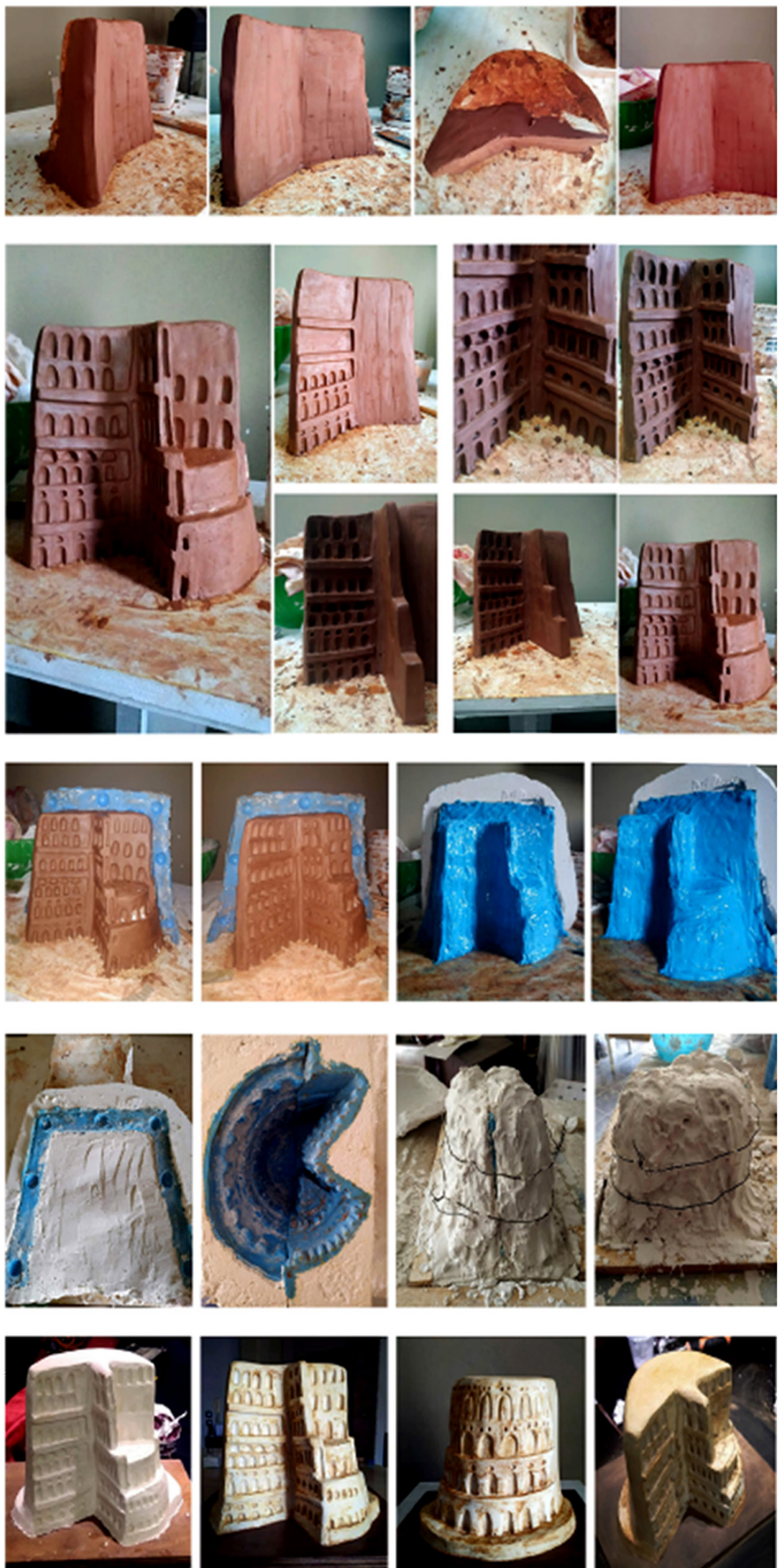


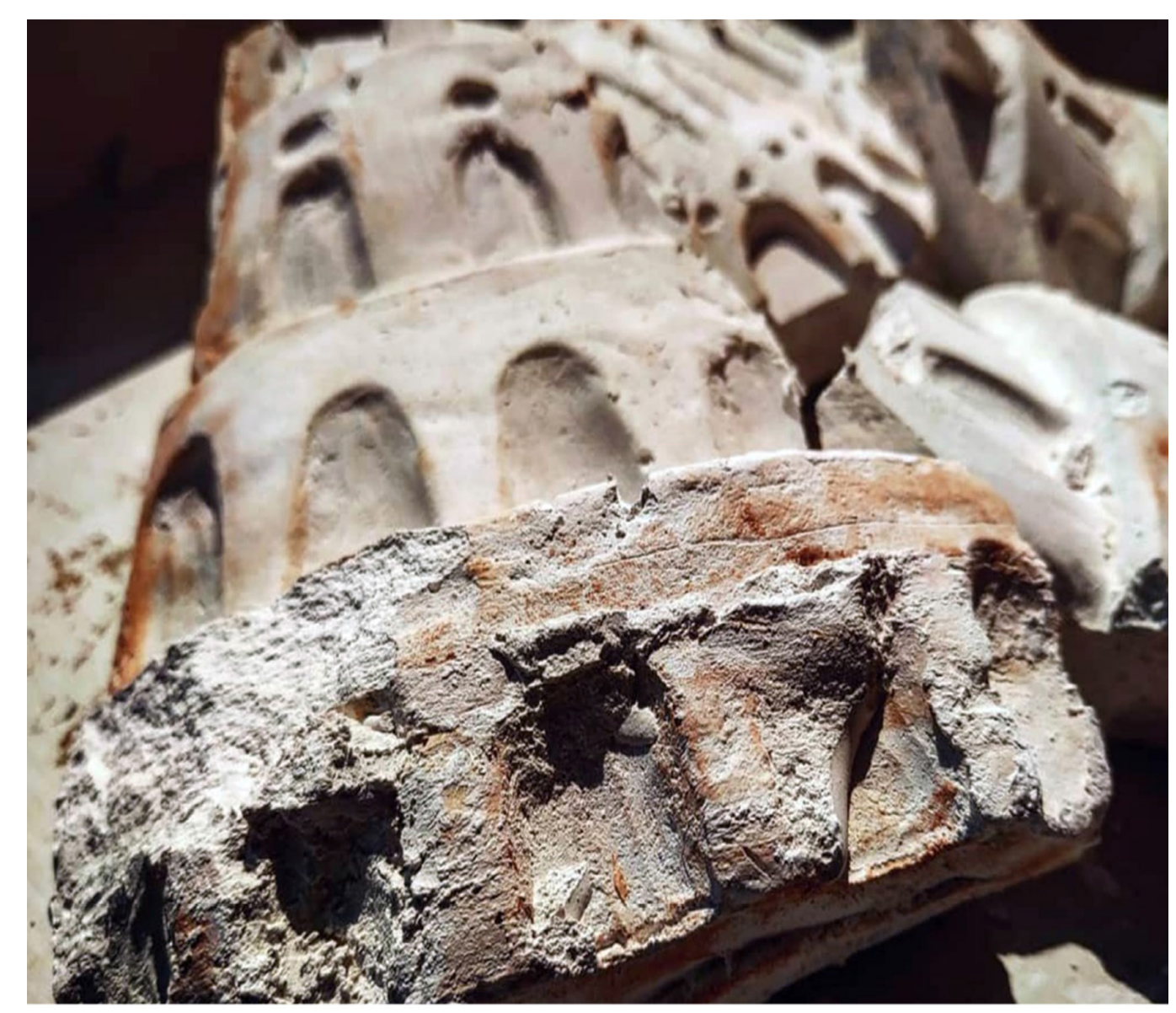

Fig. 9. Architettura del disvelamento: la rottur in gesso della Torre Babele di Pieter Bruegel. Sequenza fotografica.
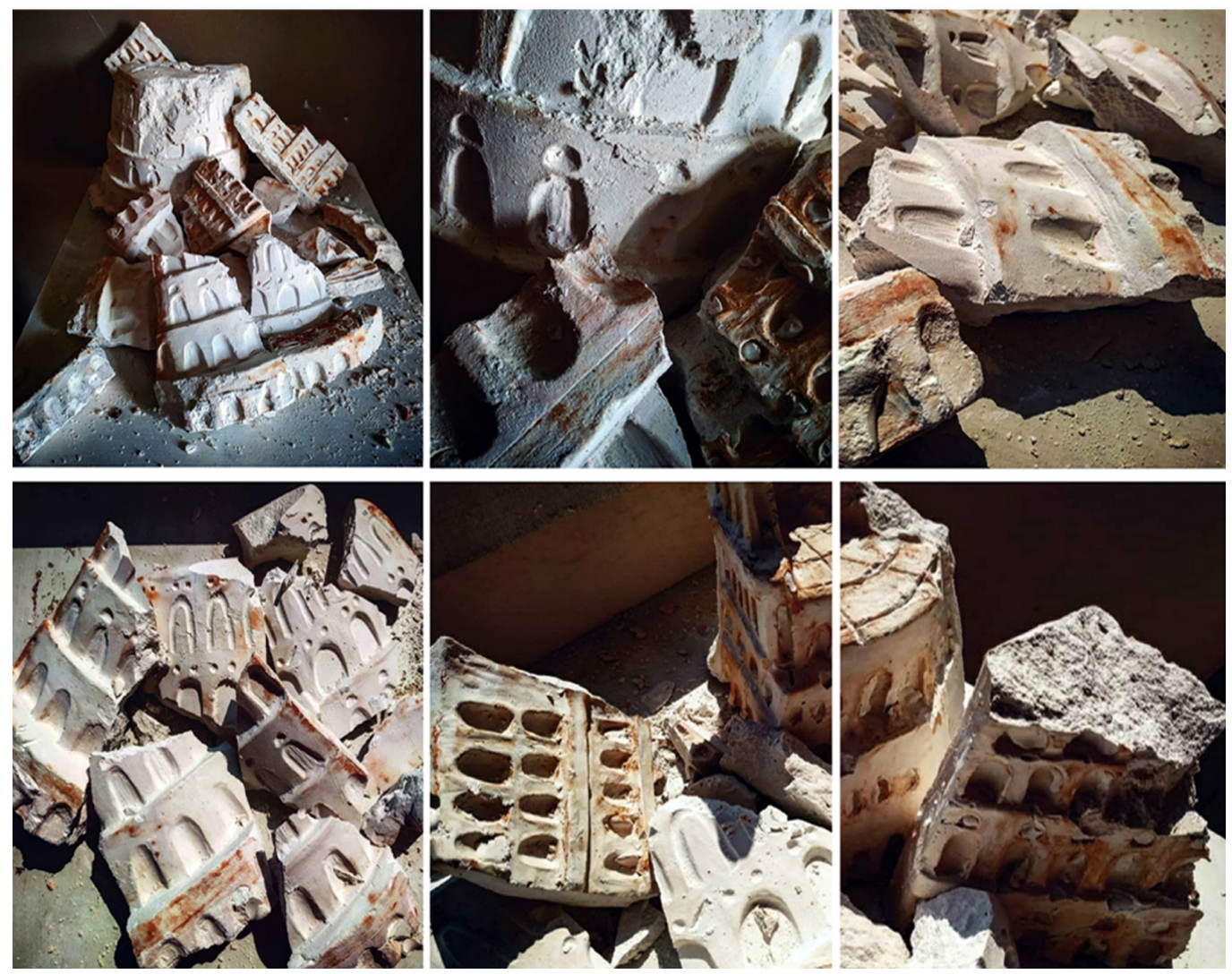

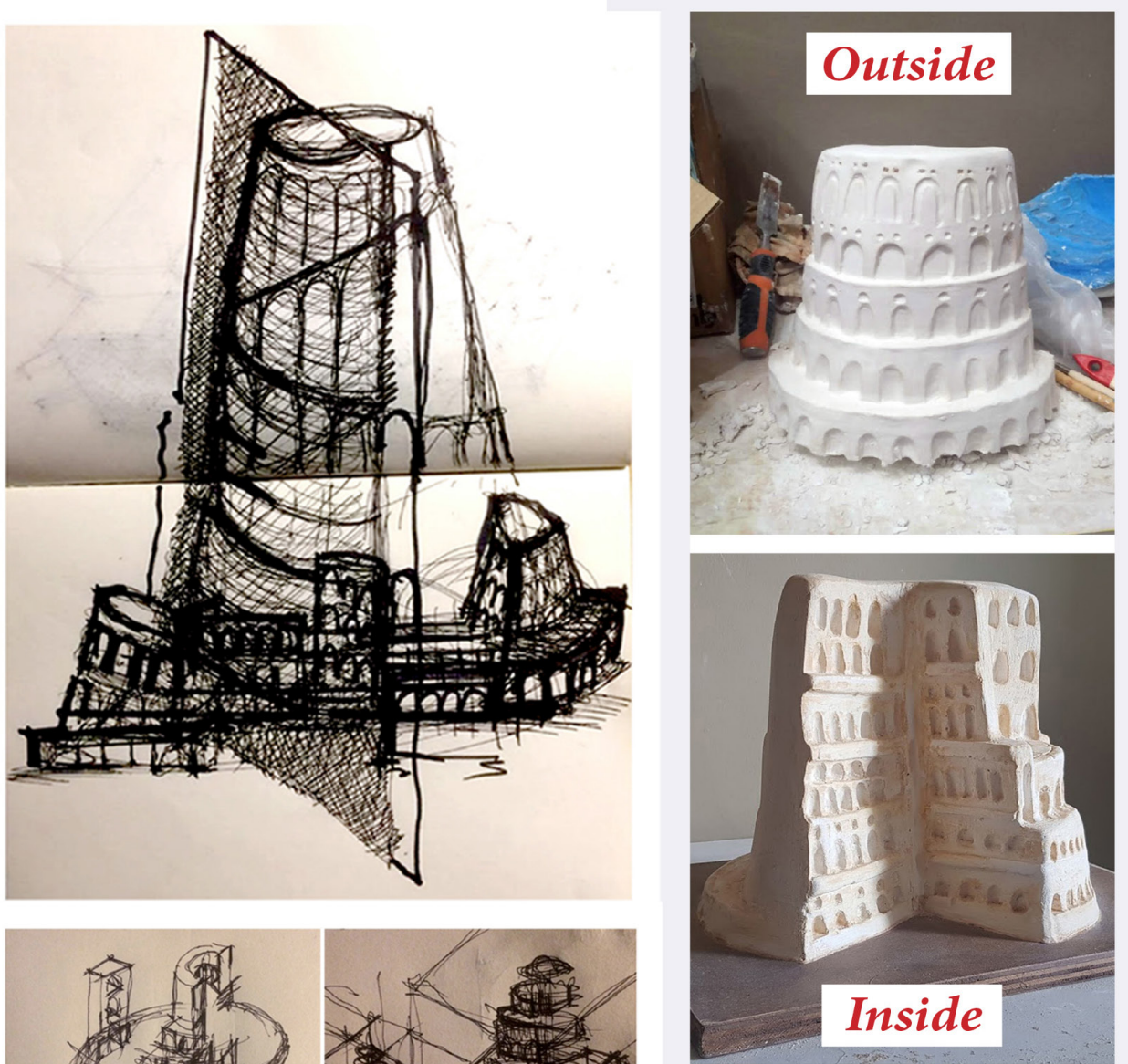

Fig. 10. Gaetano Ginex. Inside Babel, 2019. Studio per lo svuotamento della Torre di Babele di Pieter Bruegel, disegni al tratto (a sinistra)

Inside

Babel; rottura di Outside e Inside Babel, sequenza fotografica (a destra).
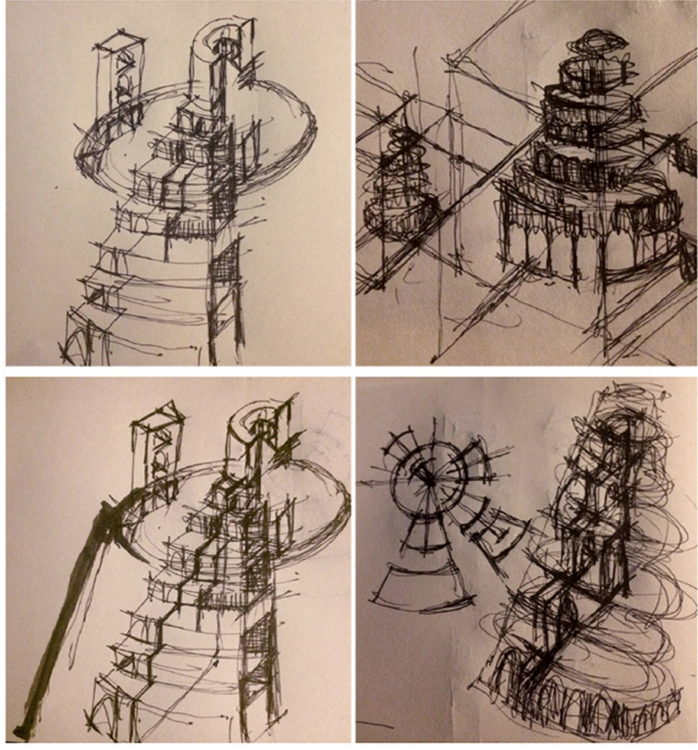

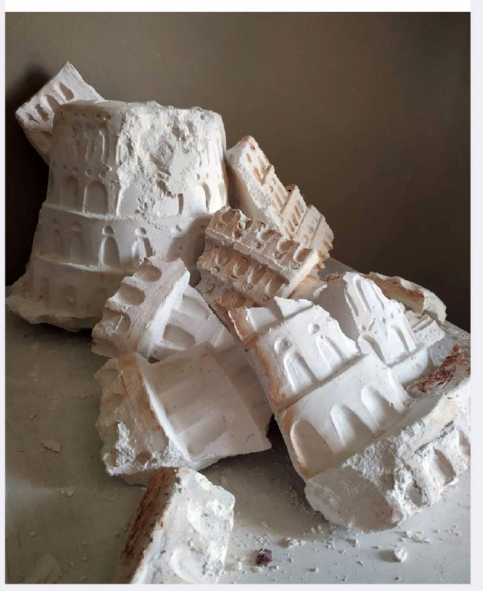

Rottura 


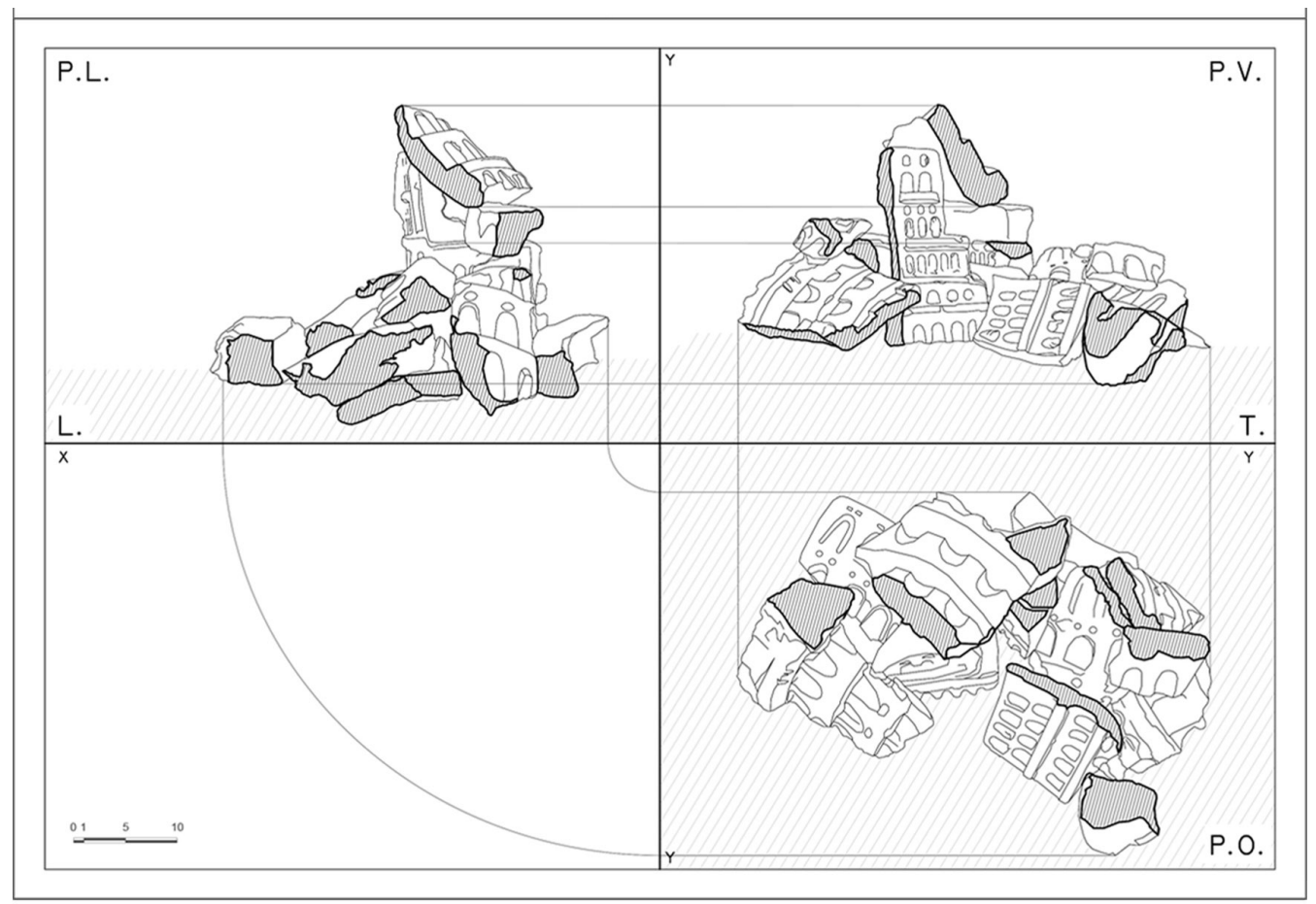

Fig. I I. Bruegel's Tower of Babel Inside. Analisi di una sezione data dalla rottura

spontanea dell'elemento.

spontanea dellemento.

ortogonali.
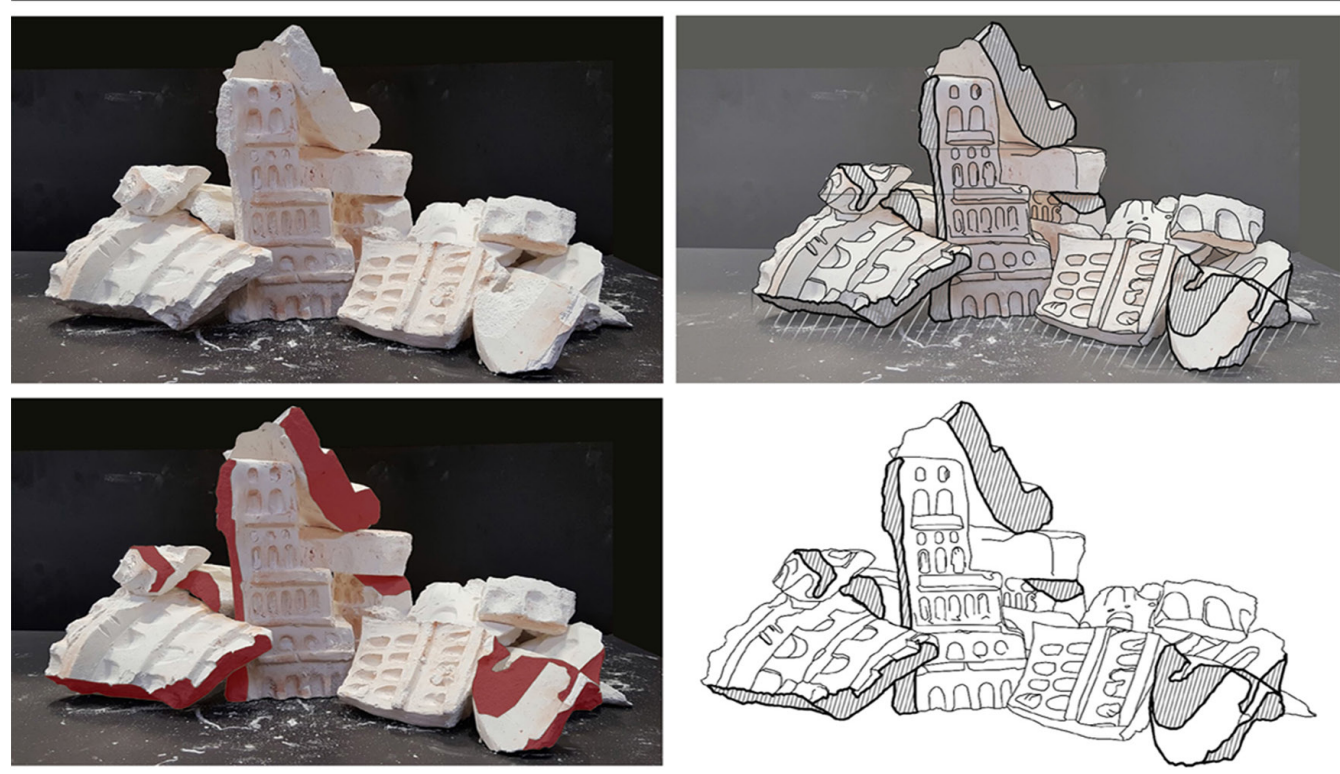
[3] Una torre frontale, bidimensionale, un'immagine.

[4] Circa $50 \mathrm{~cm}$ di lunghezza, $30 \mathrm{~cm}$ di larghezza e $30 \mathrm{~cm}$ di altezza.

\section{Riferimenti bibliografici}

Ginex Gaetano (2019). Reggio e i miti della Magna Grecia. Reggio Calabria: Città del sole.

Kircher Athanasius ( 1679). Turris Babel. Amstelodami: ex officina Janssonio-Waesbergiana.

Pizzigoni Antonia (20l I). Dalla rappresentazione di paesaggio alla ricerca sull'architettura. Scritti e acquerelli di Massimo Scolari. In: Pizzigoni Antonia. Educazione all'architettura. Milano: FrancoAngeli, pp. I-24.

Rossi Aldo (1987). Frammenti. In Alberto Ferlenga (a cura di). Architetture 1959- 1987. Milano: Electa.

Scolari Massimo (1987). Prototipi e archetipi urbani. In Belli Gabriella, Rella Franco (a cura di). La città e le forme. Atti del convegno 'Città: forma e significato', Trento, dicembre 1985, pp. 27. Milano: Mazzotta.

Scolari Massimo (1979). Principi compositivi. In Rassegna n. I, Recinti, pp. 4 I-44.

Scolari Massimo (199|). Glider, Antonia Jannone. Disegni di Architettura, Milano: <http://www.massimoscolari.it/?page_ $\mathrm{id}=\mid 86>$.

Autore

Chiara Pietropaolo, Università degli Studi Mediterranea di Reggio Calabria, chiarapietropaolo89@gmail.com

Per citare questo capitolo: Pietropaolo Chiara (2020).Turris Babel inside. II disvelamento della materia tra frammento e rottura/Turris Babel Inside. The Unravelling of Matter between Fragment and Breakage. In Arena A., Arena M., Brandolino R.G., Colistra D., Ginex G., Mediati D., Nucifora S., Raffa P. (a cura di). Connettere. Un disegno per annodare e tessere. Atti del $42^{\circ}$ Convegno Internazionale dei Docenti delle Discipline della Rappresentazione/Connecting. Drawing for weaving relationships. Proceedings of the 42th International Conference of Representation Disciplines Teachers. Milano: FrancoAngeli, pp. I330-1355. 


\title{
Turris Babel Inside. The Unravelling of Matter between Fragment and Breakage
}

\author{
Chiara Pietropaolo
}

Abstract

The research deals with a rather unique theme from the point of view of the representation of the tower of babel in the history of art.

Turris Babel acquires a new visual meaning as the research takes a way for discovery and interpretation of it from its interior, thanks to the concept of 'vision', parameters based for the mutation process of iconic shape of the tower.

A new meaning and a new representative shape are therefore discovered, through a material modelling of the tower model that 'breaks' the traditional configuration, creating its formal transformation. the breakage, the less of matter, release new figures and new 'visions', allowing to develop, in a renewed field of investigation, a study whose results undertake the possibility of deeply affecting the shape of architecture, changing its initial configuration.

Case study of the research is the most iconic of the towers produced by the Flemish art of the XVI century: the 'big tower of babel' by Pieter Bruegel the Elder (I563). New ways of representation are therefore found in this search and are space for new 'visions', in the eternal representation of a timeless archetype, fundamental paradigm for the iconography of the most discussed tower in the history of humanity.
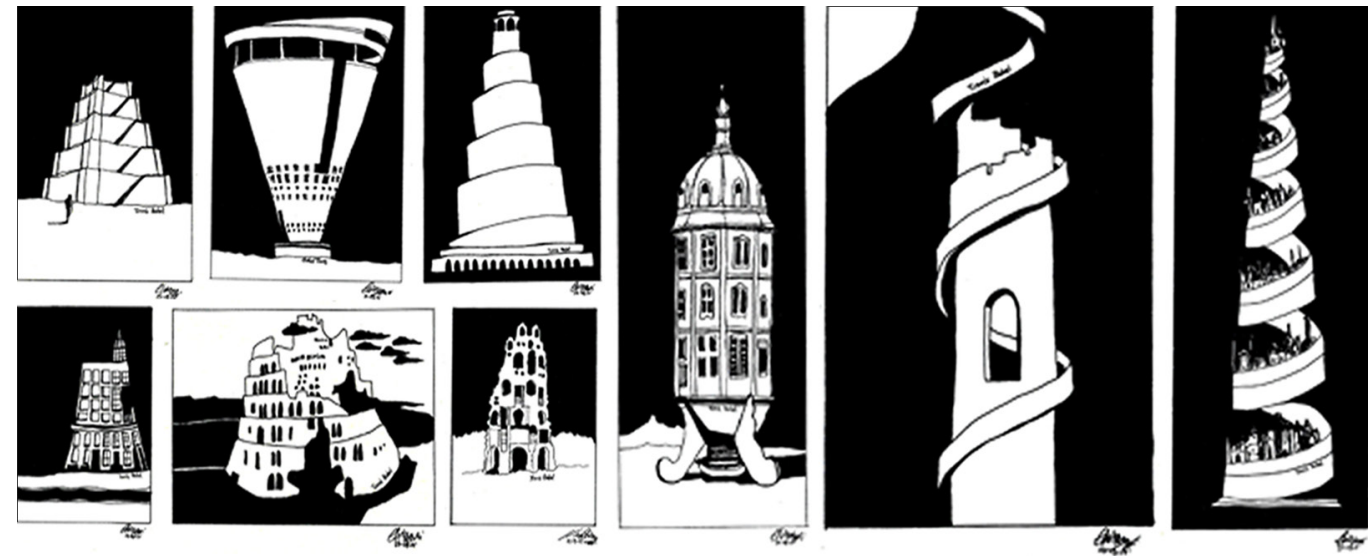
[Massimo Scolari]

\section{Architecture of shape. The function of the archetype}

"The Archetypes laconically show us the way to formal precision and accuracy. They are the basic forms of architecture studied in its relationship with nature, seen independently of its context" [Scolari 1979, p. 44].

It is in fact in the figures of the archetypes, in that "respect for the Archetype" that, as Scolari says, we are opposed to the "obstinate innovation", rediscovering the nature of the machine of architecture: the Tower of Babel is one of these very first examples [Scolari 1991, p. 7], one of the most investigated archetypes, occurring with great frequency in the history of art. It represents the natural steps of the mountains transformed into architecture, therefore the origin of construction.

Thus, Babel embodies the primitive concept of disclosure of a symbolic, literary, archaeological-architectural, mythological-biblical and literary heritage. It brings together a plural cultural background, and is part of a theme that embraces the global knowledge of human knowledge.

The choice of this theme starts from the observation that the study of the architectural typology of the tower represents the most widespread architectural and urban model in the history of ancient architecture since the earliest civilizations. Therefore, this archetypal figure is highlighted in its material and immaterial expressions, above all through painting, where the theme is a pretext for arguing the procedures of representation (figs. I , 7).

A valuable contribution from the point of view of the archetypal paradigms underlying the shape of the tower of Babel, was generated by the researches of Hermann Kern and Paolo Santarcangeli, and with them Baltrusaitis, Borges, Eco, Hillman, Jung and Kircher, which in his Turris Babel [Kircher 1679] shows us an interesting reflection on the theme of the tower as an ancestral archetype, from a scientific point of view.

In the foreground, we see it 'split' at its center and divided into two diametrically opposite but congruent parts. Something permeates its center. Something goes through that rift. A breakage, a laceration which however generates a fragment. A new image. A new vision. A Babel, Inside.
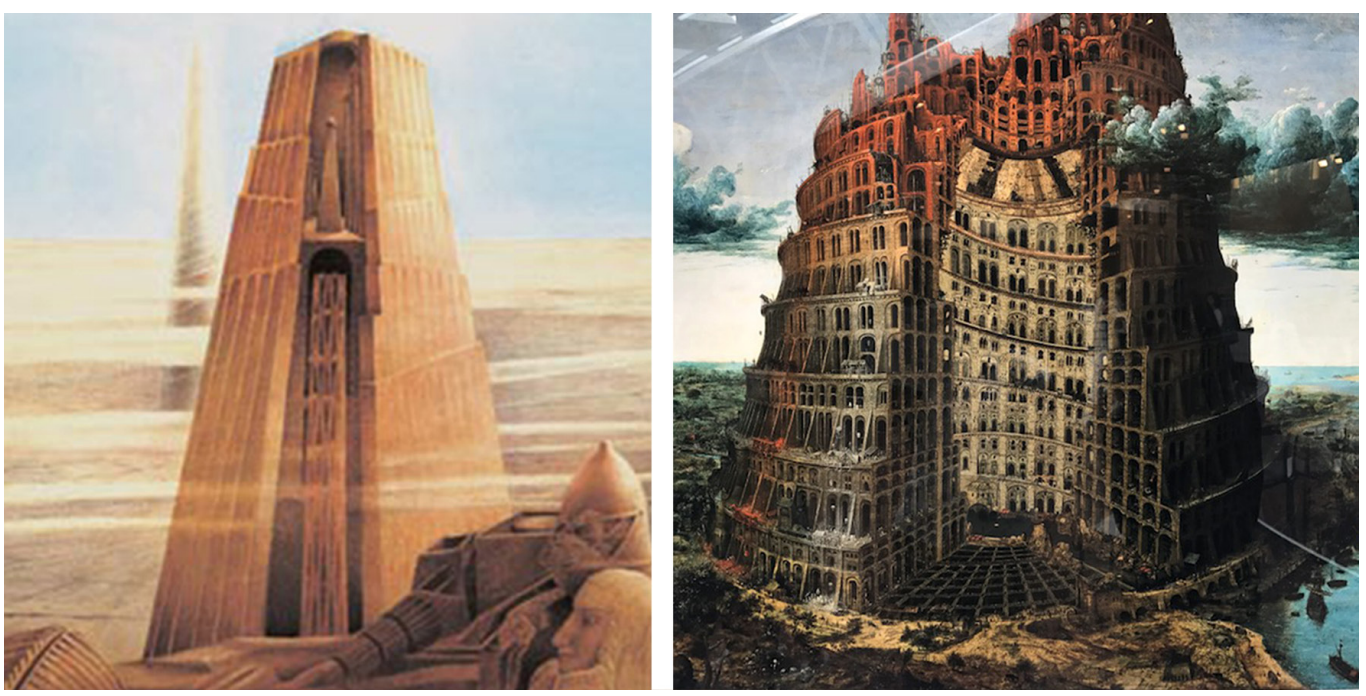
As for the formal concept, an original aspect of the research in relation to this archetype, it is due to Scolari, who recognizes the identity between the tower as an elevated construction and the rift that is generated inside it. A void is therefore created which must be filled, thus becoming a full, that is, a second architecture.

We can therefore see that something permeates the center of the tower. Something goes through that rift. A breakage, a laceration which however generates a fragment. A new image. A new vision. A Babel, Inside (fig. 2). In a sense, there is an intent in Massimo Scolari to dig deep. To seek the hidden side of things.

This is why we combine this masterpiece with Katsuhiro Otomo's 'Inside Babel' [I]: in the common aim of seeking architectural interiority, both artists produce visions that are part of a research project. A project that goes beyond the historical utopian visions of the 'whole'Tower. The idea arises from the fundamental principle of conducting research on shape, through a series of figures, seen as the breakdown of complex sets.

In confirmation of this assumption, we can affirm that the tower of Babel appears as the element of certainty in the research that finds in these elements the archetypal figures and the principles to which to entrust the substance of the choices made [Pizzigoni 201 I, pp. I- 17].

Fig. 2. Architectures of the Vision. Studies for the extrapolation of the pictorial Vision in the case study. Bruegel's Tower of Babel Inside Vision, 2019 (graphic elaboration by Chiara Pietropaolo.
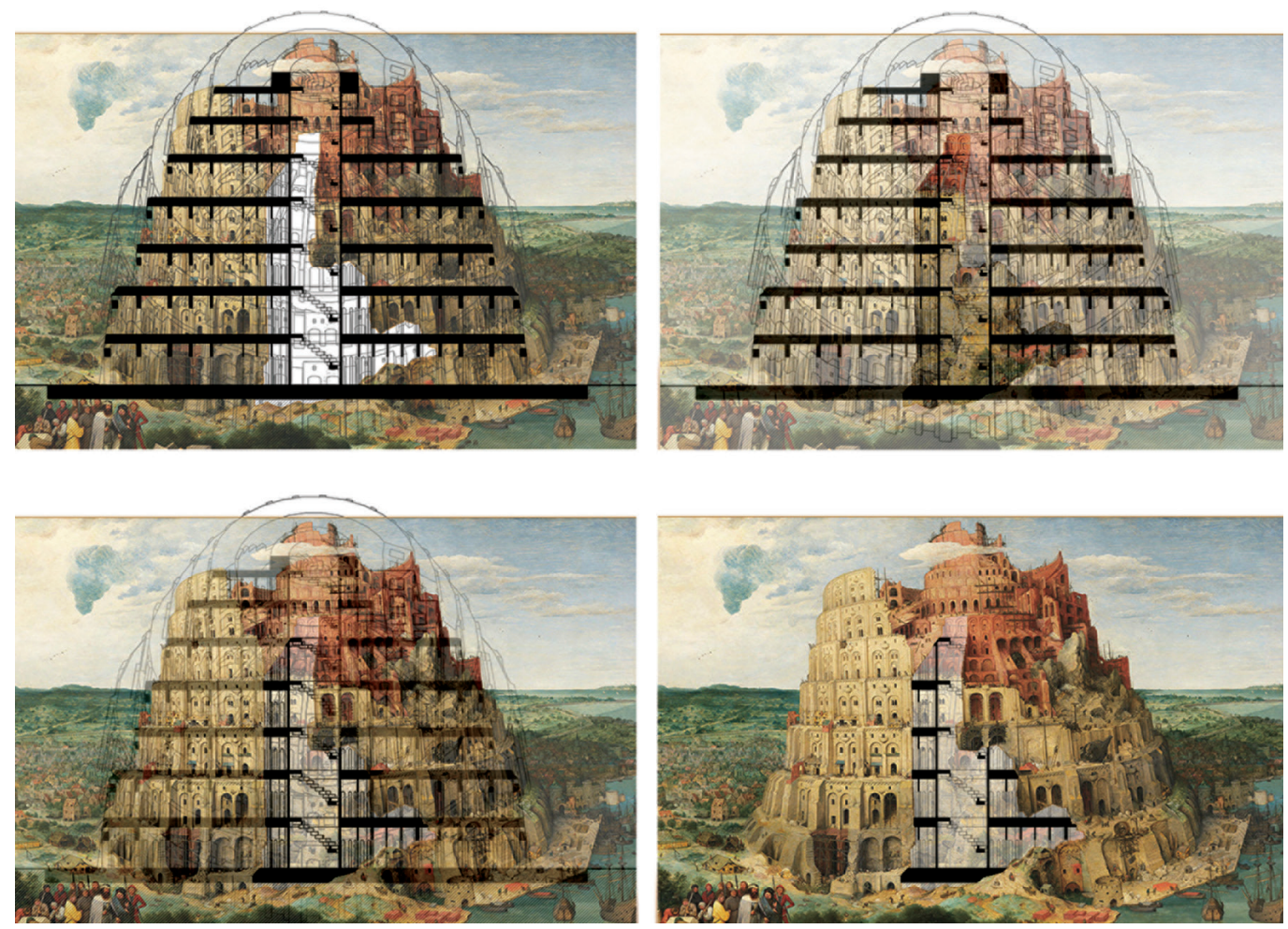

\section{Breakage and transformation. Turris Babel Inside Vision: the unravelling of matter}

But archetypes are also synthetic images that do not always materialize in projects that respond to the demands of established reality. Precisely for this reason they are rich in meaning and are called 'visionaries'.

They need a look that comes out of the city and its geographical features, to take on the symbolic value that research pursues so much.

Architectures of the 'limit points' are therefore in the clearest and most evident way those archetypes that mark the passage between two worlds. And Turris Babel fully embodies this concept of transition between the earthly world and the celestial world. Once again, the reference to Otomo's work is more fitting than ever. 
Fig. 3. From painting to the 'stripping' of the model as a method of unravelling the material. The 'small tower' of Babel by Pieter Bruegel according to Otomo.
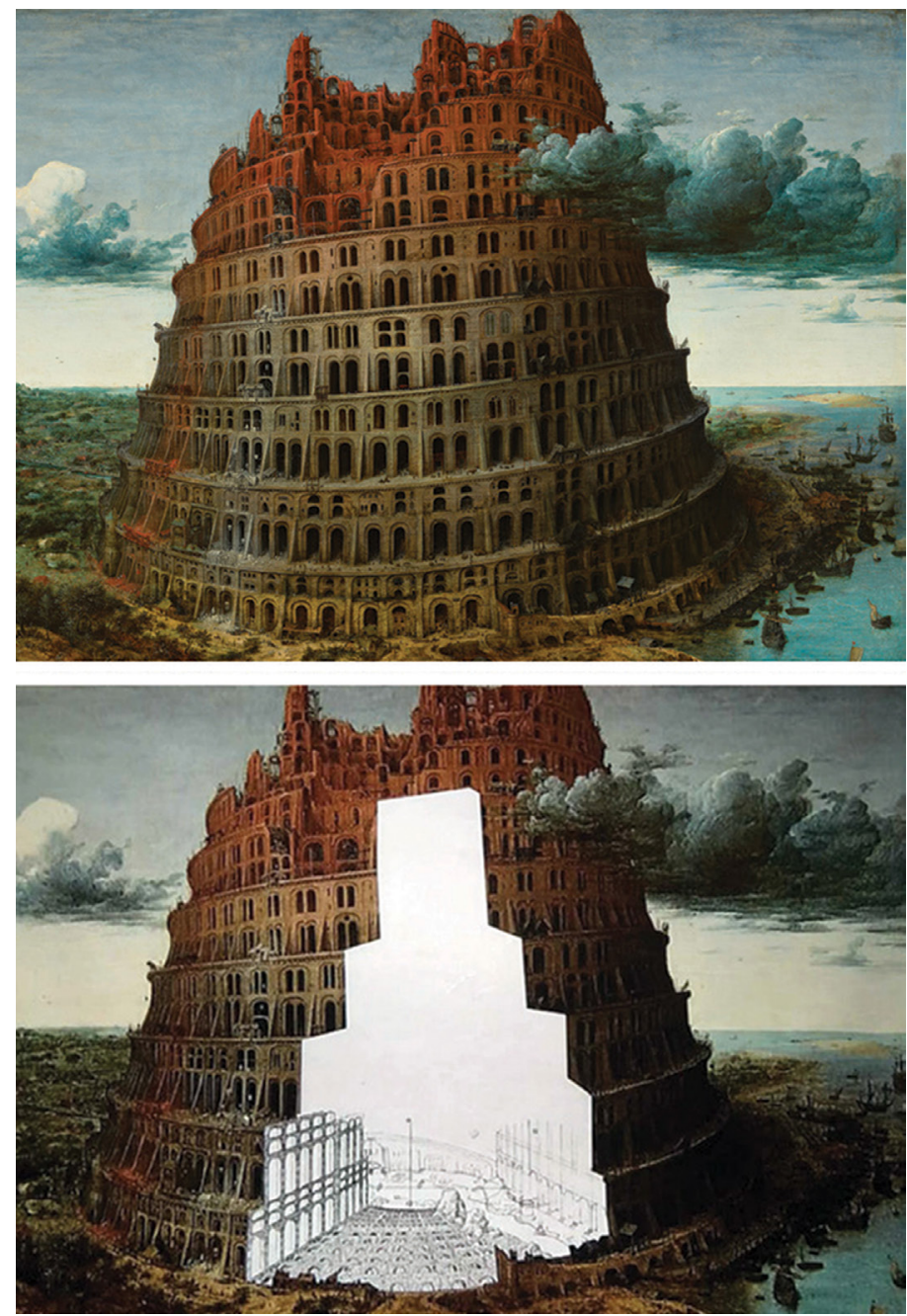

The Turris Babel shows itself to our eyes 'inside', internally, from a point of view that 'tears' it inside, dug deep, 'stripped', becoming itself a 'fragment', a new 'fragment' that it comes to life from the breakage, from the laceration of the architectural object (the Tower), which is itself an Archetype, one of those fundamental archetypes in the history of architecture, and which generates something new: a vision. 'Inside Babel' therefore assumes a 'visionary' character, it becomes a utopian project adhering to the visionary nature of earthly things which, however, cast a glance projected towards the future (figs. 3, 4, 5).

To demonstrate this, the representations of Massimo Scolari recur, which intertwine well with the themes of research on Turris Babel. In particular, on the concept of 'breakage' and 'fragment' of architecture, precisely because in them we find summarized some of the founding elements of the visionary story.

The staging of a parallel world, in which the apparent nostalgia for the architectural archetypes of ancient Middle Eastern and Mediterranean cultures is kept at bay by a gaze loving the enigma. Therefore each project linked to them will be a 'visionary' project, as it belongs to this world which is opposed to the ordinariness of things and rises above another dimension, which lies above the things themselves [Pizzigoni 201 I, pp. I I I] .

But what is the architecture of the fragment and breakage? It could be defined as architecture of fragmentation, that architecture that generates in itself the breakage, the laceration, the digging in depth, the fading of the building types, all variants that allow a journey through its interiority in the possibility of affecting very deeply on the shape of architecture itself.

Aldo Rossi writes: "'Fragment' is a small piece detached by fracture from any body. And 
with this, it expresses a hope, still a hope, and as such it is not convenient with wreck, which expresses a multitude or an aggregate of broken things. In this diction, wreck could be the body of the future city if things were not to change and disorder was increasingly accepted and the prediction of the future little thought about. [... . For this reason, I also believe in the future city like the one where the fragments of something broken from its origin are recomposed" [Rossi 1987, p. 7].

Architecture of the fragment or breakage is also what Scolari calls 'border architecture'. A research on archetypes, elements that are constant in architecture and that do not depend on its urban condition, must necessarily start from this 'architecture of the limit'.

For Scolari, in fact, it is by investigating the architecture of the limit points that the archetypes are found. Therefore, without breakage, there is no closure. Without breakage there is no truth. And the search for truth lies in the search for interiority. This is the real goal to pursue.
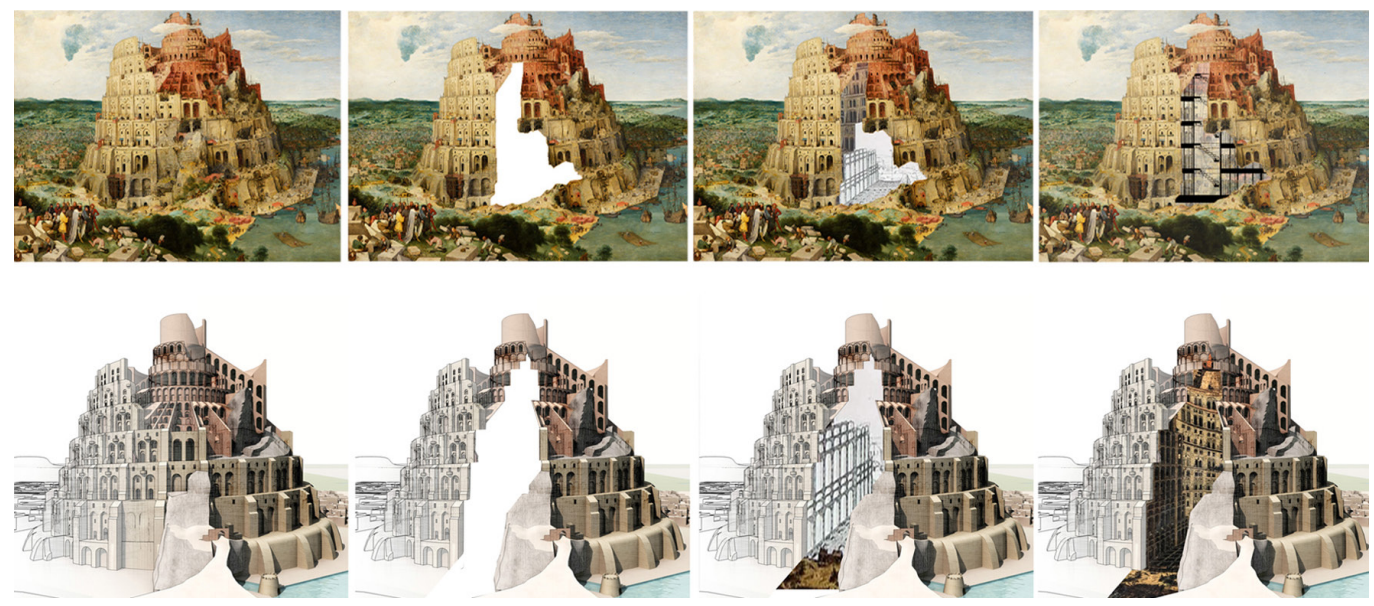

\section{A new configuration. From pictorial Vision to material Vision}

Thus, the concept of 'vision' and sight' take shape, thanks to the real construction of the Bruegel Tower of Babel, object of this study. A new method, therefore, the phase in place, for a new representation, through the analysis and elaboration of imaginary sections (Inside Sections), the extrapolation of which allowed to conduct a process of 'unravelling' the matter, as well as the creation of a 'real vision', which starts from the 'breakage' of the Outside Babel (the outer shell of the tower), and unraveil / reveals its architectural interiority [2] (fig. I I). The result is a Turris Babel that shows itself in two aspects: in it, Outside and Inside Babel coexist perfectly in a single archetype (fig. 6).

The ordinariness of the vision [3] is contrasted with a new, real, material vision, which meets the requirements of concreteness, three-dimensionality and truthfulness; determined by the creation of a plaster model, in three different versions:

I. Outside Babel model;

2. Inside Babel model;

3. Fragments generated by the breakdown of Outside Babel and Inside Babel model, through a process of unravelling the architecture of the Tower of Babel (figs. I0, I I).

The structure of the model was made of clay first and then of plaster, with consequent fragmentation of the same following a spontaneous breakage of the gypsum plaster which thus determined the interiorities from which the aforementioned sections were then generated and developed.

To this end, it is known that the 'stripping' of the model, in this final phase, takes full shape, thanks to the concrete modeling of the material (plaster), allowing to expand the visible scenario faced by Otomo. The images that follow on the following pages clearly show this path of unravelling the matter (figs. 8, 9). 

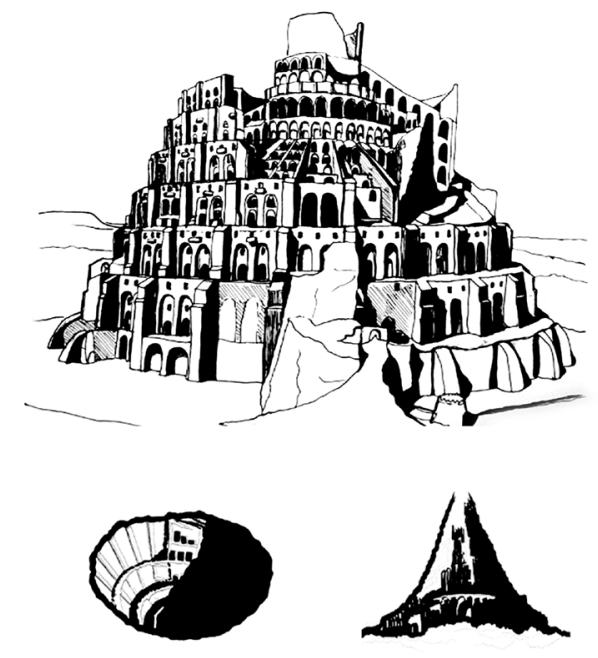

"INSIDE" BABEL

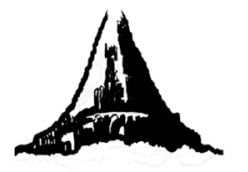

“OUTSIDE" BABEL

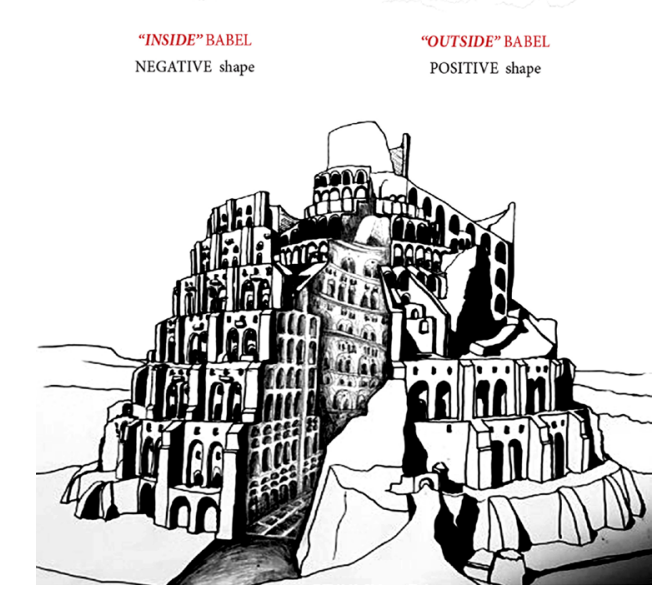

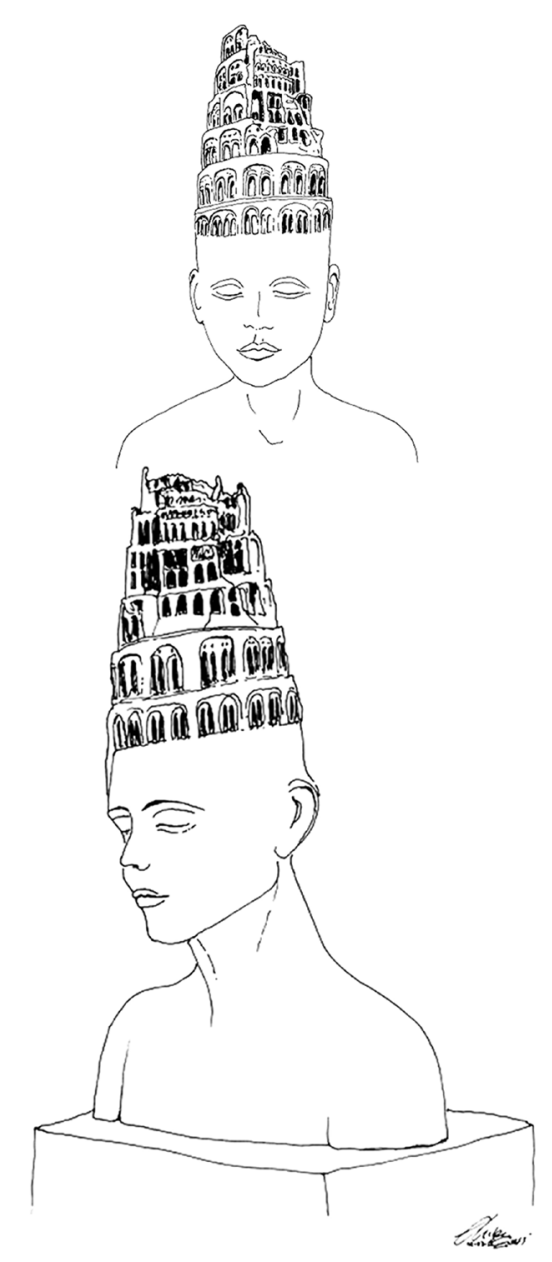

Fig. 5. From the Outside (above) to the Inside

Babel: negative shape; Out-

side Babel: positive shape

(graphic elaboration by

Fig. 6. Babel Head byTania

Font, 2019 (graphic

elaboration by Chiara

Pietropaolo, 2019). 
In addition, a detailed analysis was conducted using CAD software, in order to best represent the aforementioned sections with the orthogonal projection method.

Starting from a photographic series of the various fragments caused by the breakage of the plaster Tower models (Outside and Inside), three typical sections were chosen, to be subjected to a compared study.

In them the 'broken' parts were highlighted, fragmented by the fall and / or spontaneous breakage of the chalky material, highlighting them with a reddish pigment.

Subsequently, the research extrapolated a single section of the three examined, to be analyzed in its final phase in its entirety, in order to better translate the cardinal concepts predisposed, such as 'stripping', 'breakage' and 'unravelling' of intrinsic matter inside the Tower of Babel (Inside Babel).

In fact, the unravelling of the material is followed by its not only formal but also three-dimensional representation in the true sense of the term: the research concludes its search for interiority, giving life to a typical 'Inside Section', by means of careful analysis through the orthogonal design of his fractures (fig. 12).

Specifically, one of the various sections analyzed was examined, making a photographic series of the fragments generated by the breakage of the plaster model of the Tower (Inside section type) [4].

\section{Conclusions and advancement of the research}

The research focused on the development of a 'vision', a reworking of the painted image showing it 'stripped' inside, based on the project operated by Katsuhiro Otomo for the 'small'Tower of Babel by the well-known Flemish painter Bruegel.

Making a translation of the model shown by the Japanese master, we proceeded to the construction of the plaster model, applying the 'emptying' (Inside Babel) of the 'great'Tower of Babel by Bruegel himself.

About the three models created, the architecture of the Tower was then unraveiled, with consequent collection and cataloging of the results finally obtained.

The ultimate goal was to have demonstrated through the forms of representation that utopian architecture that becomes myth in the archetype of the tower, in its material and immaterial values.

The breakage, the loss of matter, has freed new figures and new "visions", allowing to develop, in a renewed field of investigation, a study whose results undertake the possibility of profoundly affecting the shape of architecture, changing its initial configuration.

The added value lies in having tried to offer original methods of interpretation, contributing to the transmission of a utopian model that takes on value as a memory for the representation of identity values that are constituted as irreplaceable assets for the history of humanity. And research exactly this has tried to build.

This procedure is served to see Turris Babel in depth, interpreting it in its exact size, the one hidden inside the building conventionally intended, but not perceived intimately.

To bring to light his strength and his expressive power it was necessary to dig deep. A depth accessible only in the world of 'vision'. A vision that reveals the real essence of the Tower.

\section{Notes}

[I] See the work about Katsuhiro Otomo, "Inside Babel', in two versions, both exhibited in a recent exhibition resulting from the collaboration of the Museum Boijmans Van Beuningen in Rotterdam, who 'sent' his Collection Bruegel's. The Tower of Babel and Great 16 th Century Masters in Japan, hosted at the Tokyo Metropolitan Art Museum and subsequently at the National Museum of Art in Osaka in 2017.

[2] The Inside Babel designed by Otomo and contextualized in the research thanks to the phase in progress which was thus able to translate the 'graphic vision' or visual into 'material vision' or real.

[3] A two-dimensional front tower, an image.

[4] About $50 \mathrm{~cm}$ long, $30 \mathrm{~cm}$ wide and $30 \mathrm{~cm}$ high. 


\section{OUTSIDE BABEL}

$-1^{\circ}$ fase: Bozzetto scultoreo

$-2^{\circ}$ fase: Modellazione

Preparazione dello scheletro di sostegno

$-3^{\circ}$ fase: Modellazione

Modellazione in argilla (corpo) e gesso (base)
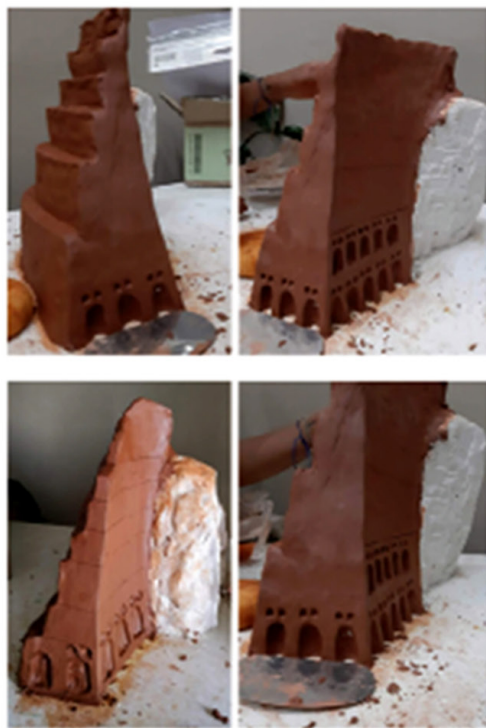

- $4^{\circ}$ fase: Modellazione

Disegno, incisione e rifinitura degli archi dell'involucro esterno ("Outside Babel")

$-5^{\circ}$ fase: Formatura in Silicone 1. Preparazione dei richiami per la forma in silicone

2. Stesura del primo strato in silicone

$-6^{\circ}$ fase: Formatura in Gesso

1. Realizzazione del controstampo in gesso scagliola

2. Formatura del primo positivo in gesso

Fig. 7. Processing phases Tor of the Tower of Babel by shell - Outside Babel.
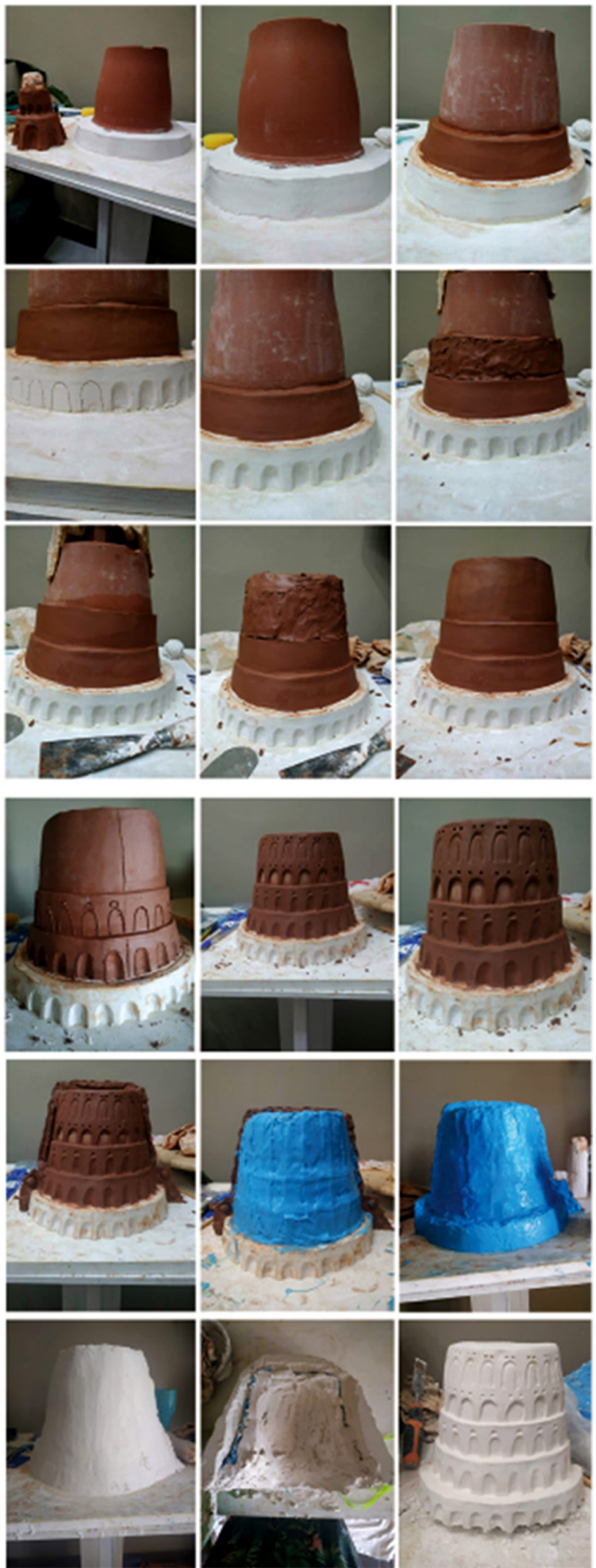


\section{INSIDE BABEL}

- $7^{\circ}$ fase: Modellazione

Modellazione in argilla

del volume interno alla

torre ("Inside Babel")

- $8^{\circ}$ fase: Modellazione

Disegno, incisione e

rifinitura degli archi dello spaccato interno ("Inside Babel")

$-9^{\circ}$ fase: Formatura in Silicone

1. Preparazione del modellato per la realizzazione del negativo in silicone 2. Stesura del silicone per la realizzazione del negativo in gesso scagliola

$-10^{\circ}$ fase: Formatura in Gesso

1. Realizzazione di uno stampo bivalve

2. Realizzacione di un controstampo di contenimento 3. Formatura del modello in gesso scagliola (positivo)
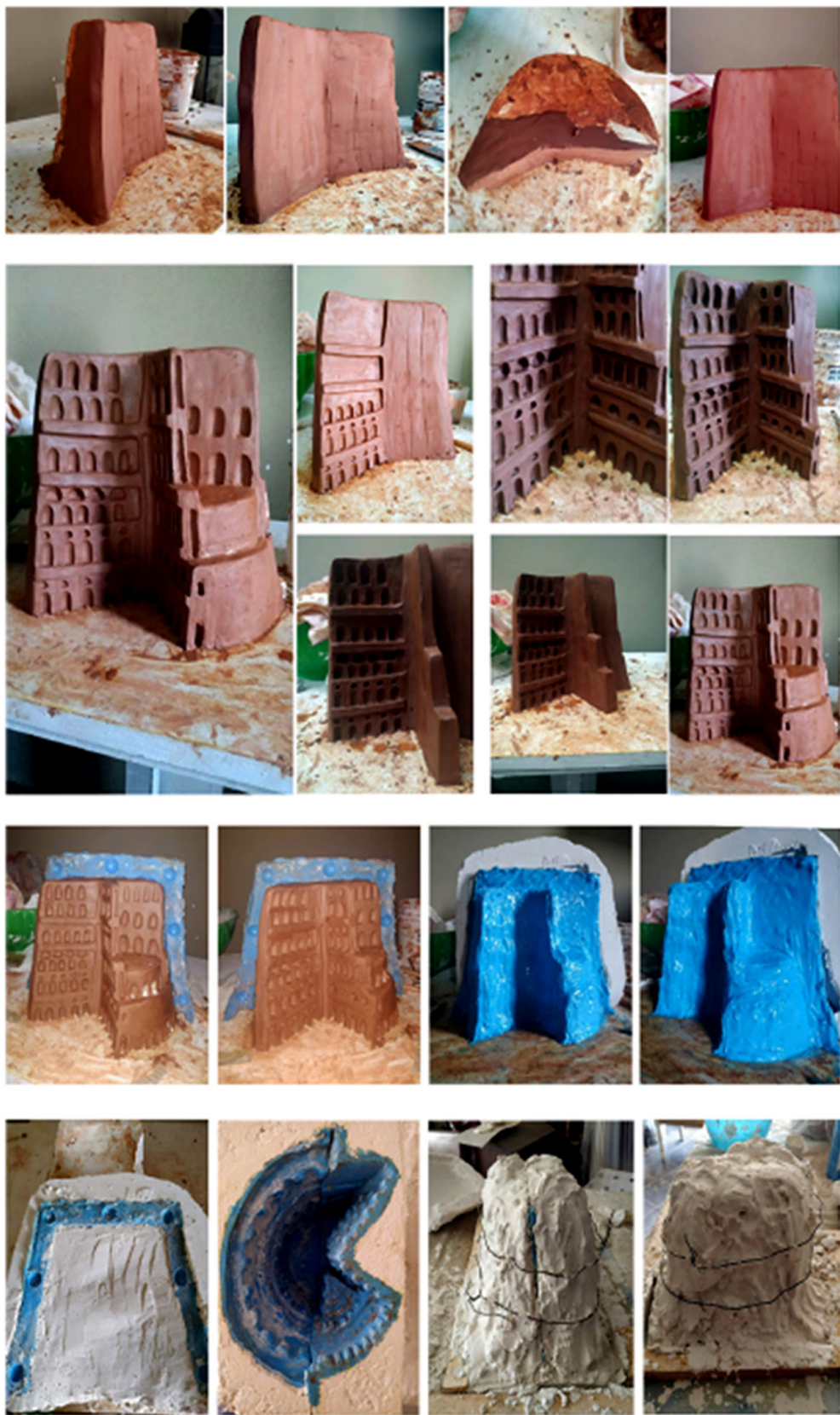

$-11^{\circ}$ fase: Sformatura e Rifinitura

1. Sformatura e rifin tura del modello in gesso scagliola

2. Patinatura
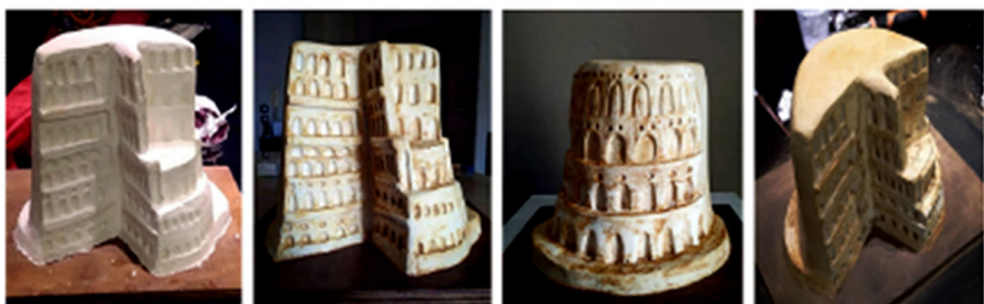


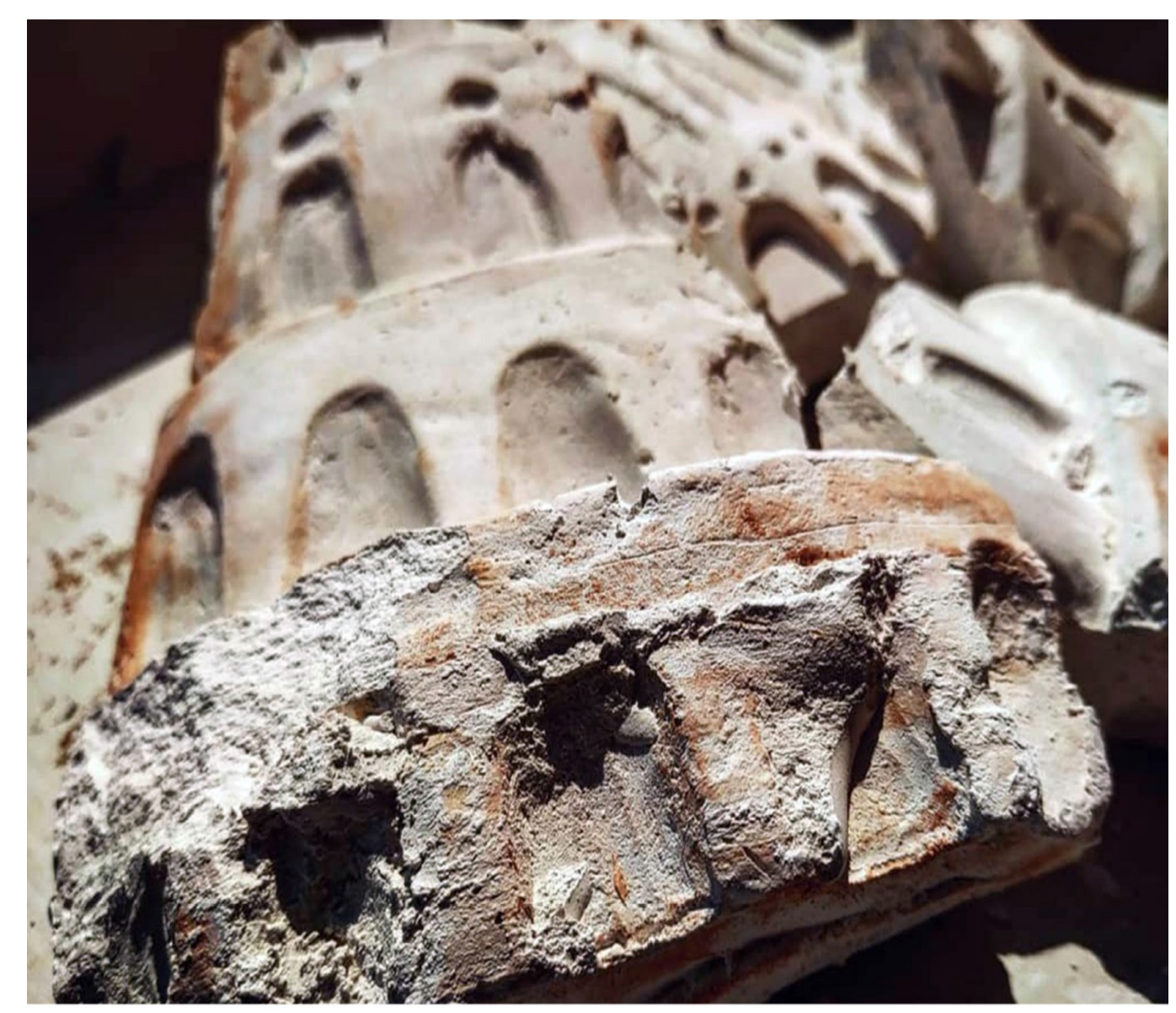

Fig. 9. Architecture of unravelling: the Breakage. Inside Babel. Plaster Babel by Pieter Bruege Photographic sequence.
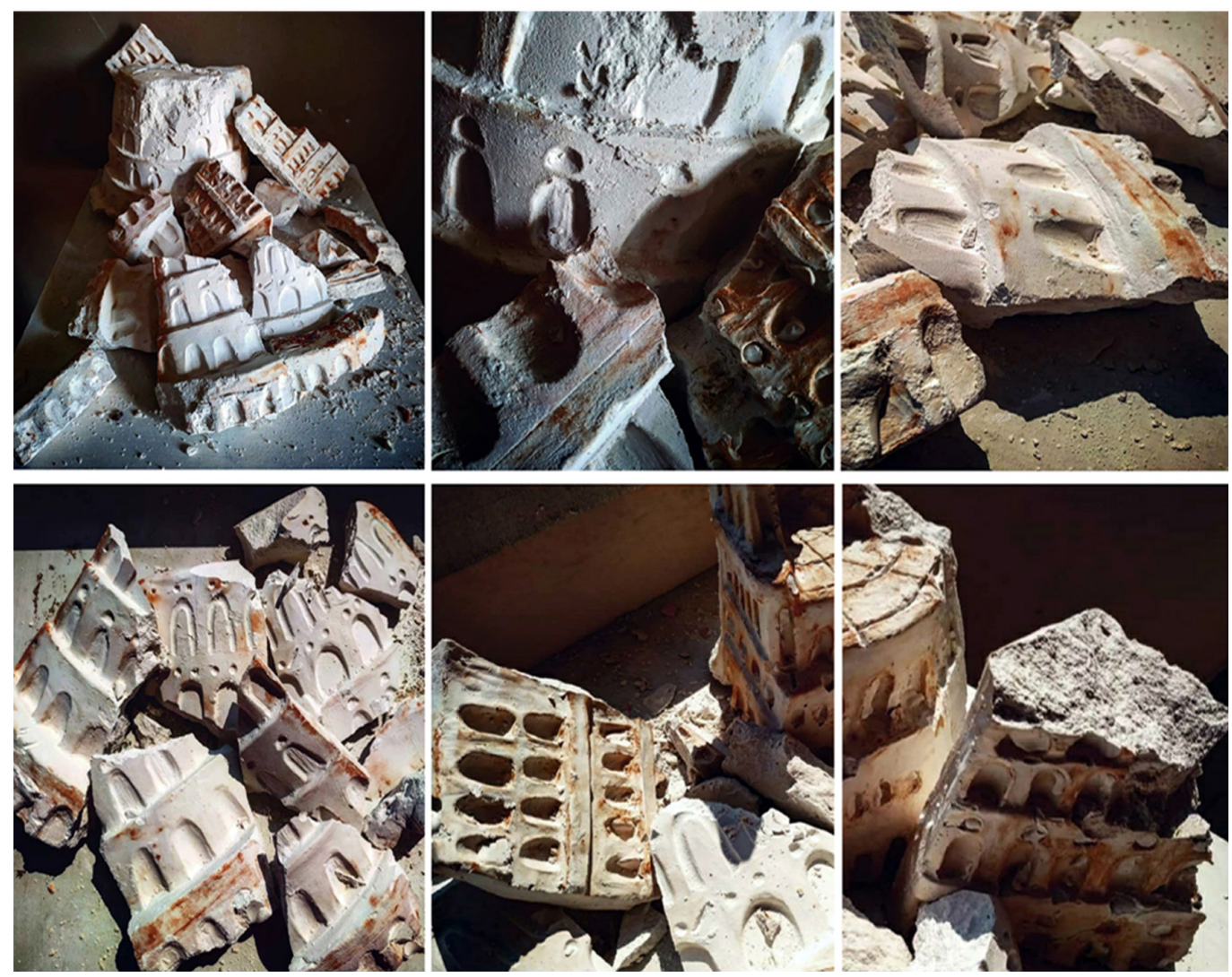
Fig. 10. Gaetano Ginex. Inside Babel, 2019. Inside Babel. Study for the

emptying of the Tower of

Babel by Pieter Bruegel.

ine drawings (on the

eft). Outside Babel:

Inside Babel; breaking of

Dutside and Inside Babel.

Photographic sequence
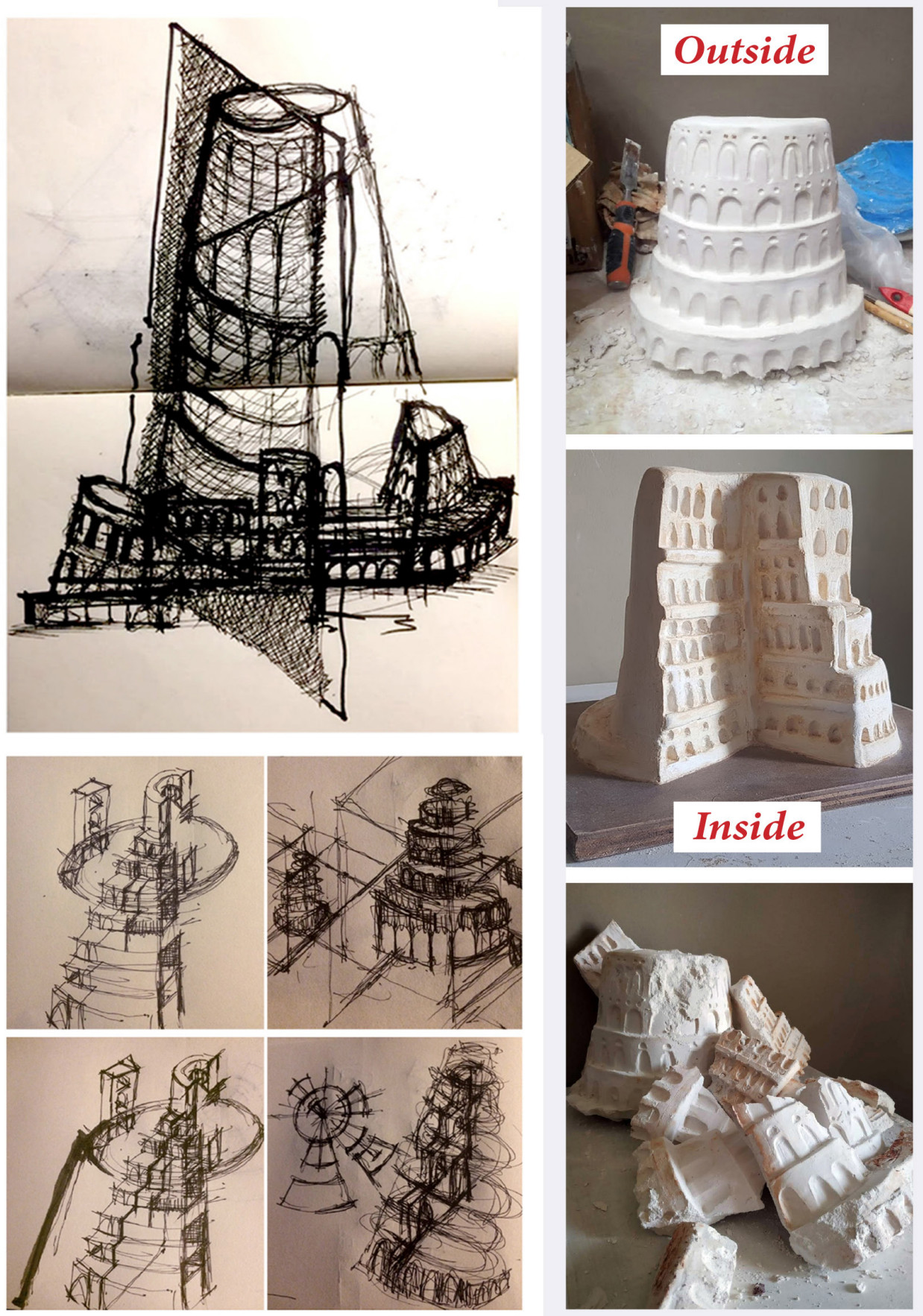

Rottura 

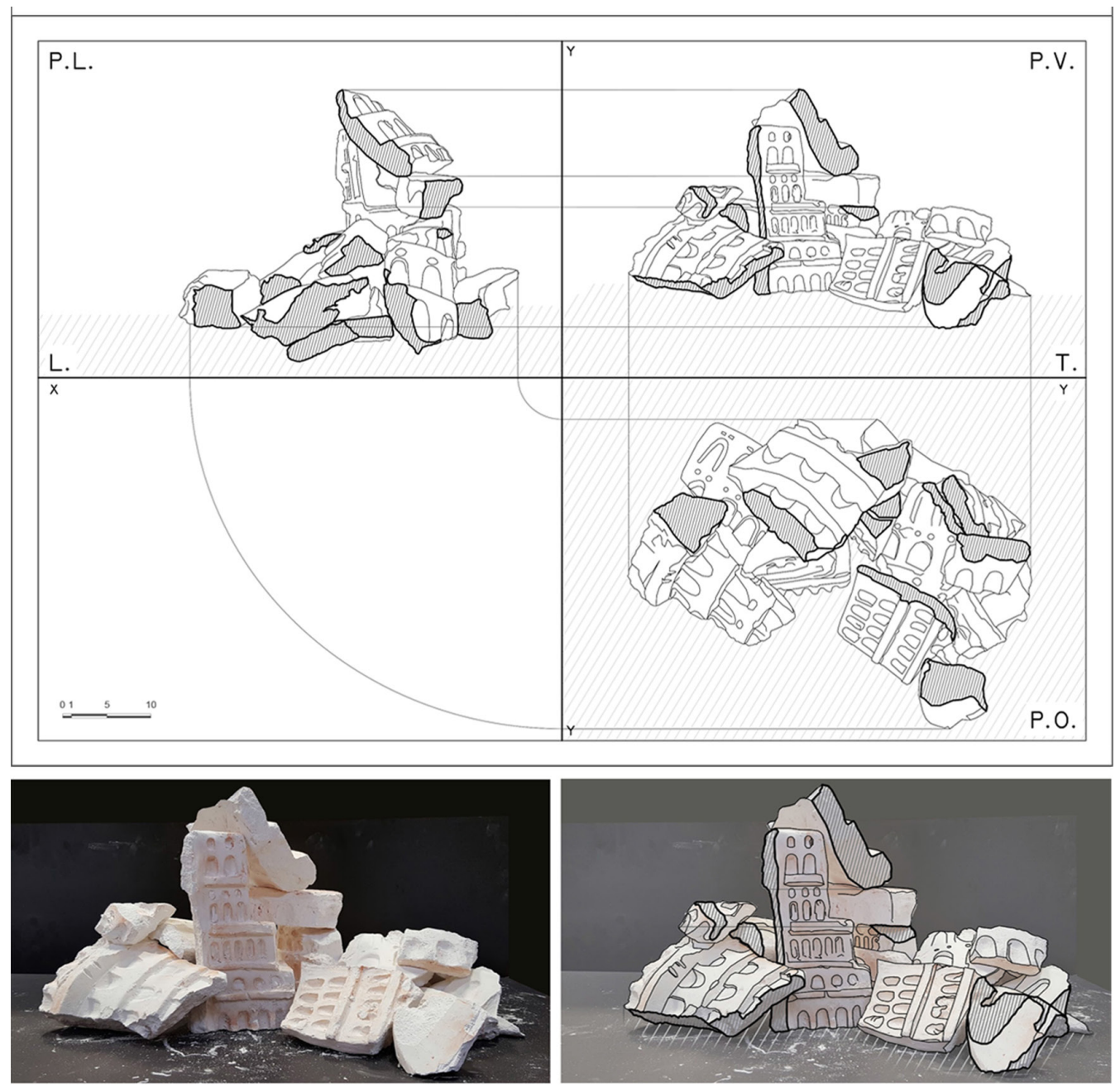

Fig. I I. Bruegel's Tower of Babel Inside. Analysis of a section given by the spontaneous breakage of

spontaneous breakage of projections method.
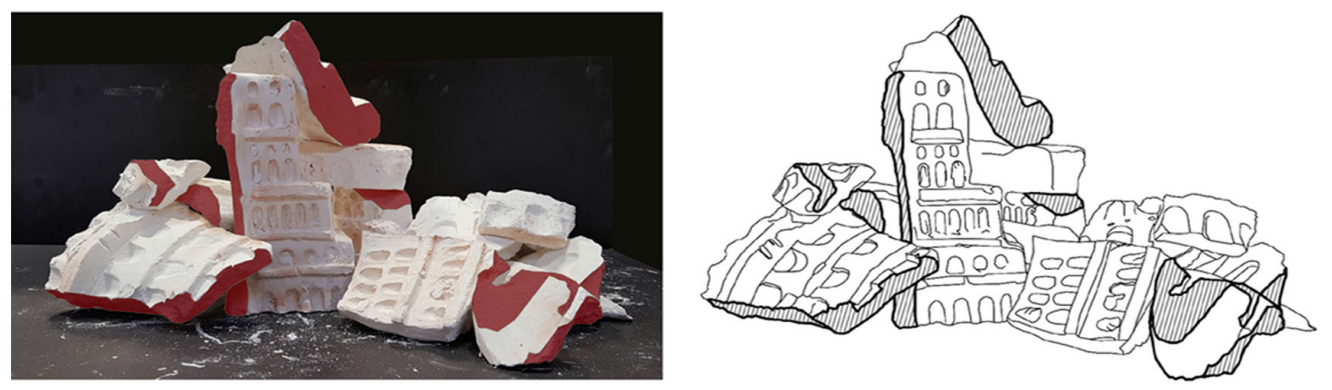


\section{References}

Ginex Gaetano (2019). Reggio e i miti della Magna Grecia. Reggio Calabria: Città del sole.

Kircher Athanasius ( 1679). Turris Babel. Amstelodami: ex officina Janssonio-Waesbergiana.

Pizzigoni Antonia (20II). Dalla rappresentazione di paesaggio alla ricerca sull'architettura. Scritti e acquerelli di Massimo Scolari. In: Pizzigoni Antonia. Educazione all'architettura. Milano: FrancoAngeli, pp. I-24.

Rossi Aldo (1987). Frammenti. In Alberto Ferlenga (a cura di). Architetture 1959- 1987. Milano: Electa.

Scolari Massimo (1987). Prototipi e archetipi urbani. In Belli Gabriella, Rella Franco (a cura di). La città e le forme. Atti del convegno 'Città: forma e significato', Trento, dicembre 1985, pp. 27. Milano: Mazzotta.

Scolari Massimo (1979). Principi compositivi. In Rassegna n. I, Recinti, pp. 4 I-44.

Scolari Massimo (199|). Glider, Antonia Jannone. Disegni di Architettura, Milano: <http://www.massimoscolari.it/?page_ id $=\mid 86>$

Author

Chiara Pietropaolo, Università degli Studi Mediterranea di Reggio Calabria, chiarapietropaolo89@gmail.com

To cite this chapter. Pietropaolo Chiara (2020).Turris Babel inside. II disvelamento della materia tra frammento e rottura/Turris Babel Inside. The Unravelling of Matter between Fragment and Breakage. In Arena A., Arena M., Brandolino R.G., Colistra D., Ginex G., Mediati D., Nucifora S Raffa P. (a cura di). Connettere. Un disegno per annodare e tessere. Atti del $42^{\circ}$ Convegno Internazionale dei Docenti delle Discipline della Rappresentazione/Connecting. Drawing for weaving relationships. Proceedings of the 42th International Conference of Representation Disciplines Teachers. Milano: FrancoAngeli, pp. $1330-1355$. 